IZA DP No. 6791

Spouses' Retirement and Hours Outcomes:

Evidence from Twofold Regression Discontinuity with Differences-in-Differences

Elena Stancanelli

August 2012 


\title{
Spouses' Retirement and Hours Outcomes: Evidence from Twofold Regression Discontinuity with Differences-in-Differences
}

\author{
Elena Stancanelli \\ CNRS, Sorbonne Economics Research Center, Paris 1 University, \\ IZA and OFCE, Sciences-Po
}

Discussion Paper No. 6791

August 2012

IZA
P.O. Box 7240
53072 Bonn
Germany

Phone: +49-228-3894-0

Fax: +49-228-3894-180

E-mail: iza@iza.org

\begin{abstract}
Any opinions expressed here are those of the author(s) and not those of IZA. Research published in this series may include views on policy, but the institute itself takes no institutional policy positions.

The Institute for the Study of Labor (IZA) in Bonn is a local and virtual international research center and a place of communication between science, politics and business. IZA is an independent nonprofit organization supported by Deutsche Post Foundation. The center is associated with the University of Bonn and offers a stimulating research environment through its international network, workshops and conferences, data service, project support, research visits and doctoral program. IZA engages in (i) original and internationally competitive research in all fields of labor economics, (ii) development of policy concepts, and (iii) dissemination of research results and concepts to the interested public.
\end{abstract}

IZA Discussion Papers often represent preliminary work and are circulated to encourage discussion. Citation of such a paper should account for its provisional character. A revised version may be available directly from the author. 


\section{ABSTRACT \\ Spouses' Retirement and Hours Outcomes: Evidence from Twofold Regression Discontinuity with Differences-in-Differences ${ }^{*}$}

Earlier studies conclude that spouses' retirement strategies are not independent from each other and that policies affecting individuals in a couple are also likely to affect the economic behaviour of their partner. In this study, we exploit retirement age legislation in France as well as a retirement policy change to identify the effect of own and spousal retirement on spouses' hours. To this end, we use a Fuzzy Regression Discontinuity approach combined with Differences in Differences, for both spouses. The data for the analysis are drawn from French Labour Surveys pooled over thirteen years. The sample for the analysis includes over 85,000 dual-earner couples with spouses aged 50 to 70 . We find evidence of large and significant jumps in the own retirement probability at the legal early retirement age for both men and women in a couple. We also conclude that the 1993 reform reduced significantly the probability of retirement at the early retirement age for married men while the effect was not significant for married women. Husbands' retirement probability increases significantly when the wife reaches early retirement age while her retirement probability is not responsive to his early retirement age. We conclude that hours fall significantly upon own and partner's retirement for both spouses. On average, her hours fall by 2.7 per cent when he retires while his hours fall by 5 per cent when she retires, implying an average reduction of one hour per week for women and two hours for men if their spouse retires.

JEL Classification: J14, C1, C36, D04

Keywords: $\quad$ ageing, retirement, regression discontinuity, policy evaluation

Corresponding author:

Elena Stancanelli

CNRS - Centre national de la recherche scientifique

3 , rue Michel-Ange

75794 Paris cedex 16

France

E-mail: elenastancanelli@free.fr

\footnotetext{
* This paper was written while visiting Cambridge University. I am indebted for suggestions to Arthur Lewbel, Hamish Low and Arthur van Soest. All errors are mine.
} 


\section{Introduction}

There is growing interest in the retirement strategies of individuals in a couple. Earlier studies suggest that individuals in a couple time their retirement closely together. Therefore, retirement policies affecting the retirement decision of one spouse directly may also have indirect effects on the retirement decision of the other spouse. However, spouses may not only retire at a close time, but the wife (husband) may also, possibly as an alternative to full retirement, reduce her (his) hours if her husband (his wife) has retired from work.

In this study, we exploit the legal early retirement age in France as well as a retirement policy change to estimate the causal effects of spouses' retirement on spouses' hours.

The literature on joint retirement decisions of partners is quite scant. Most earlier studies build on structural models to argue that partners tend to retire together because of leisure complementarities -to enjoy spending free time together (see, for example, Alan Gustman and Thomas Steinmeier, 2000). Gustman and Steinmeier (2009), also from a structural standpoint, argue that in some cases individuals in a couple may decide to retire only if their partner does not retire. Stancanelli and van Soest (2012a and 2012b) using data drawn from the 1998-99 French Time Use Survey, and applying a double Regression Discontinuity approach, conclude that there are significant asymmetries in house work and leisure of partners after retirement. ${ }^{1}$

To date, little is known on whether and how retirement policies affecting the economic behavior of one partner may also change the behavior of the other partner. Blau (1998) estimates a structural model of joint labour force transitions of older married couples to investigate the effects of increasing one spouse's Social Security benefit at age 65. He finds significant but small reductions in the own and cross retirement probability for both spouses. Baker (2002) studies the effect of the introduction of an allowance for dependent spouse in the Canadian social security system on labour force participation of spouses, to conclude that this policy reduced labour force participation rates of eligible women and their husbands. Kanika Kapur and Jeannette Rogowski (2007) study the effect of employer-provided retiree health insurance (assumed exogenous by the authors) on the retirement behaviour of dual-

\footnotetext{
${ }^{1}$ Stancanelli and van Soest (2012a and 2012b) did not consider spouses' hours responses or model retirement policy changes. They used a small cross-sectional time diary dataset of 1000 couples at a snapshot point in time.
} 
earners in the USA, findings evidence of asymmetric effects for partners: the wife's health insurance increases joint retirement while the husband's does not.

Here we study the causal effect of spouses' retirement on spouses' hours using the discontinuity in the individual retirement probability at the legal early-retirement age to identify retirement in our model. We also control for a 1993 policy change that increased the length of the pension contribution years necessary to retire with the maximum (full) pension benefits for younger cohorts, among other things. ${ }^{2}$ The 1993 reform is likely to have reduced the probability to retire at the legal early retirement age for the younger cohorts -by making them less likely to retire with full pension benefits if they retired early.

Because spouses are typically a few years apart, we can identify both own and partner's retirement in our model. Therefore, we specify a four simultaneous equation model of retirement and hours of both spouses. We use information on the day of the interview to identify hours. Firms typically have to satisfy orders by a certain day of the month.

The data for our analysis are drawn from the French Labour Force Surveys (LFS) 1990-2002. These yearly surveys are comparable over time as they use the same questionnaire, the same data collection method (personal interviews at the respondent's home) and the same sample design. The French LFS series was broken in 2003 to comply with Eurostat requirements: as from 2003 interviews are carried out quarterly, mostly by telephone; and the questionnaire and the sample design have changed dramatically relative to the earlier LFS surveys. Besides, another reform of the length of the pension contribution period took place in 2003, which is exactly the time of the break in the LFS series. Therefore, we select a sample of dual-earners couples from the 1990-2002 yearly LFS with both spouses aged between 50 and 70. This gives a sample of over 85000 couples.

We find evidence of large and statistically significant jumps in the own retirement probability at the legal retirement age for both men and women in a couple: the increase in the retirement probability is equal to 0.30 for married men and 0.33 for married women. Furthermore, we conclude that the 1993 reform that required younger cohorts born after 1933 to pay longer pension contribution periods, reduces the probability to retire at the early retirement age for married men (by 0.08) while the effect is not significant for married women. Married men are

\footnotetext{
${ }^{2}$ See, for example, Antoine Bozio (2004), who studied the effect of the 1993 reform on the retirement age of individuals, using a cross-section of French administrative data on pension contribution records, and with a differences-in-differences approach, to conclude that those affected by the reform postponed their retirement significantly.
} 
also more likely to retire (by 0.05) if their wife reaches early retirement age while the opposite is not true for married women. We conclude that hours of both spouses fall significantly upon own and partner's retirement. On average, her hours fall by 2.7 per cent when he retires while his hours fall by 5 per cent when she retires, implying a reduction of one hour per week for married women and two hours for married men, if their spouse retires.

These findings are robust to selecting couples with at least one spouse aged 50 to 70 , or narrowing the bounds for the regression discontinuity design, and various other robustness checks.

\section{The empirical model}

\subsection{The RD design}

Our objective is to study the effect of spouses' retirement on spouses' hours. We are especially interested in the cross-effects: does his (her) retirement after her (his) hours? Individuals' hours decisions are unlikely to be independent from retirement decisions. Therefore, we model spouses' retirement and hours decisions simultaneously. To identify spouses' retirement, we exploit exogenous variation in the retirement probability of partners due to the discontinuity in each partners' retirement probability at age 60 , which is the legal early retirement age for most workers in France. ${ }^{3}$ There are no other policies that affect individuals of age 60 in France; ${ }^{4}$ and age cannot be manipulated by the respondents. Therefore, we use a Regression Discontinuity (RD) approach to identify retirement in the hours equations. This approach has several advantages that have been carefully discussed by, for example, David Lee and Thomas Lemieux (2010); Wilbert van der Klaauw (2008); and Guido Imbens and Thomas Lemieux, (2007). Essentially, because individuals close to the discontinuity cut-off (age 60 in our case) on the two sides of the age cut-off are likely to be very similar, a regression discontinuity design is very close to an experimental design and

\footnotetext{
${ }^{3}$ See, for example, Blanchet, Didier and Louis-Paul Pele (1997) or Bozio, Antoine (2004) for details of the French pension system. In 2010, legal early retirement age was set at 62 years, with effect, however, only as from 2018. Jean-Olivier Hairault, Francois Langot and Thepthida Sopraseuth (2010) model the employment effect of the distance to legal retirement age in France, within a theoretical job search framework, to conclude that increasing legal retirement age is likely to increase employment rates of older workers.

${ }^{4}$ Other policies are targeted at older unemployed workers, aged 55 and above, that are allowed not to search for jobs ("dispenses the recherches d'emploi") or at employers, that have to pay some large penalty to be able to fire older workers, aged above 55 ("Contribution Delalande"). See Bommier, Roger and Magnac (2003) for an analysis of both policies and their effects on French labour market dynamics. Here we restrict the sample for analysis to dual-earner couples (see Section 3).
} 
requires fewer assumptions than, for example, other techniques such differences-indifferences, which rely on finding a control group similar to the treatment group.

Under a "sharp" RD design, the probability of retirement would increase by hundred per cent at the age cut-off point, i.e. everyone would retire when they reach age 60. However, some individuals may retire earlier, due to different sector of employment rules or special early retirement plans, and others may retire later, because they may not have cumulated enough pension contributions by the time they reach age 60 to be able to obtain maximum (full) pension benefits -and thus they will continue to work a few extra years past age 60 to retire later with larger pension benefits. To account for this, we use a "fuzzy" RD design (see, for example, David Lee and Thomas Lemieux, 2010, for more details of this approach) that allows for a jump of less than one in the probability of retirement at the age cut-off of 60 years.

The pension benefits payable reach a maximum when individuals have cumulated a given contribution record (for example, 40 years of contributions in 1994 for people born in 1944 and working in the private sector). Once individuals have contributed enough to retire with maximum (full) pension benefits, their pension benefits will not increase if they retire later. Furthermore, periods of unemployment or sick leave, including maternity and parental leave, all lead to full (100 per cent coverage of) pension contribution records. Therefore, we expect the jumps at age 60 in the retirement probability to be very tangible -and indeed this is the case for both partners, which validates our identification strategy.

The LFS surveys collected month and year of birth of respondents together with records of the day, month and year of the interview, and retirement status was measured at the interview date, thus we assume that age is measured continuously -and of course, individuals cannot control their age.

Furthermore, we control for a reform introduced in 1993 that required younger cohorts of individuals, born after 1933, to contribute between one and ten extra quarters to the pension fund (depending on the year of birth) to be able to obtain maximum (full) pension benefits upon retirement. The 1993 reform also affected the amount of full pension benefits payable, by making this last a function of the best 25 years $^{5}$ of wages instead of the best ten years of

\footnotetext{
${ }^{5}$ This reform was implemented gradually, so that these would be the best 11 years for individuals born in 1934 and the best 25 years for those born in 1944 (see Bozio, 2004, for more details).
} 
wages, which was the rule before 1993, and by linking the benefits payable to the inflation rate instead of the wage growth rate.

We model the 1993 reform using a differences-in-differences approach, by defining cohorts born after 1933 as the treatment group and cohorts born in 1933 and earlier as the control group. The policy years are 1994 and later years and the control years, 1993 and earlier years, as the policy was announced in July 1993 and implemented as from 1994. ${ }^{6}$ The effect of the policy change on the retirement probability is captured by the interaction term between the treatment group dummy and the policy year dummy for each spouse, say "P93 $\mathrm{m}$ " for the husband and "P93 $\mathrm{f}$ " for the wife. The standard assumption for the validity of this approach is that there are no other policy changes that affect the control and the treatment group (in opposite directions) during this period of time.

Here we allow the 1993 policy change to affect spouses' retirement probabilities by including in our model full interactions of the "P93" differences-in-differences terms with the RD terms -and by including also controls for the birth cohorts and years. The 1993 policy (by increasing the length of the pension contribution period required to obtain full pension benefits) is likely to have reduced the incentive to retire at the legal early retirement age, by reducing the chances that individuals have contributed enough to obtain full pension benefits at the early retirement age.

Therefore, we use a fuzzy RD design for the discontinuity in retirement at age 60 (720 months in our design) interacted with a differences-in-differences term to capture the effect of the 1993 reform, to identify the effect of partners' retirement on partners' hours. This makes our approach essentially a double RD approach combined with a double differencesin-differences approach because we allow for both spouses' retirement in the model. Thanks to the fact that partners are on average at least two years apart, we can identify our model.

Moreover, to identify hours in our model (our objective is to estimate the effect of partners' retirement on partners' hours) we also need a variable that affect hours but not retirement. To this end, we use the day of the survey interview. Hours are likely to vary considerably over days of the month, as typically firms have to satisfy orders by a certain day of the month and

\footnotetext{
${ }^{6}$ The data collection took place for each of the LFS surveys that we use here between January and May of the relevant year, with over 95 percent of the data being collected in March. In 1993, over 99 percent of the interview took place in March.
} 
accordingly set deadlines for workers. Thus, we expect that hours will be sensitive to the day of the interview.

Finally, in a conventional fuzzy RD design, one would use an instrumental variable approach (usually two stages least squares), to estimate the model, as illustrated, for example, in David Lee and Thomas Lemieux (2010); Wilbert van der Klaauw (2008); and Guido Imbens and Thomas Lemieux, (2007) -which we also do as a robustness check.

Here, we specify a four simultaneous equation system to capture the simultaneity of partners' decisions, as follows. Let $\mathrm{R}$ be a dummy for retirement, equal to one if individuals have retired from market work and zero otherwise, and $\mathrm{H}$ be the hours of work. The subscript $\mathrm{m}$ stands for male partner and $\mathrm{f}$, for female partner.

a)

$$
H_{m}=Z_{m} \beta^{l m}+Z_{f} \beta^{l f}+S_{m} \omega^{\operatorname{lm}}+R_{m} \gamma^{l m}+R_{f} \gamma^{l f}+A g e_{m} \psi^{l m}+A g e_{f} \psi^{l f}+v^{l m}
$$

b)

$$
\mathrm{H}_{\mathrm{f}}=\mathrm{Z}_{\mathrm{m}} \lambda^{\mathrm{lm}}+\mathrm{Z}_{\mathrm{if}} \lambda^{\mathrm{lf}}+\mathrm{S}_{\mathrm{f}} \omega^{\mathrm{lf}}+\mathrm{R}_{\mathrm{m}} \delta^{\mathrm{lm}}+\mathrm{R}_{\mathrm{f}} \delta^{\mathrm{lf}}+\mathrm{Age}_{\mathrm{m}} \zeta^{\mathrm{lm}}+\mathrm{Age}_{\mathrm{f}} \zeta^{\mathrm{lf}}+v^{\mathrm{lf}}
$$

$$
\begin{aligned}
\mathrm{R}_{\mathrm{im}}{ }^{*} & =\mathrm{Z}_{\mathrm{m}} \beta^{\mathrm{rm}}+\mathrm{Z}_{\mathrm{f}} \beta^{\mathrm{rf}}+\mathrm{D}_{\mathrm{m}} \gamma^{\mathrm{rm}}+\operatorname{Age}_{\mathrm{m}} \mathrm{D}_{\mathrm{m}} \eta^{\mathrm{rm}}+\operatorname{Age}_{\mathrm{m}}\left(1-\mathrm{D}_{\mathrm{m}}\right) \pi^{\mathrm{rm}}+\mathrm{D}_{\mathrm{f}} \gamma^{\mathrm{rf}}+ \\
& + \text { Age }_{\mathrm{f}} \mathrm{D}_{\mathrm{f}} \eta^{\mathrm{rf}}+\operatorname{Age}_{\mathrm{f}}\left(1-\mathrm{D}_{\mathrm{f}}\right) \pi^{\mathrm{rf}}+v^{\mathrm{rm}} ; \mathrm{R}_{\mathrm{im}}=1 \text { if } \mathrm{R}_{\mathrm{im}}{ }^{*}>0 \text { and } \mathrm{R}_{\mathrm{im}}=0 \text { if } \mathrm{R}_{\mathrm{im}}{ }^{*} \leq 0
\end{aligned}
$$

d)

$$
\begin{aligned}
\mathrm{R}_{\mathrm{if}}{ }^{*} & =\mathrm{Z}_{\mathrm{m}} \lambda^{\mathrm{rm}}+\mathrm{Z}_{\mathrm{f}} \lambda^{\mathrm{rf}}+\mathrm{D}_{\mathrm{m}} \delta^{\mathrm{rm}}+\operatorname{Age}_{\mathrm{m}} \mathrm{D}_{\mathrm{m}} \tau^{\mathrm{rm}}+\operatorname{Age}_{\mathrm{m}}\left(1-\mathrm{D}_{\mathrm{m}}\right) \mu^{\mathrm{rm}}+\mathrm{D}_{\mathrm{f}} \delta^{\mathrm{rf}}+ \\
& + \text { Age }_{\mathrm{f}} \mathrm{D}_{\mathrm{f}} \tau^{\mathrm{rf}}+\operatorname{Age}_{\mathrm{f}}\left(1-\mathrm{D}_{\mathrm{f}}\right) \mu^{\mathrm{rf}}+v^{\mathrm{rf}} ; \mathrm{R}_{\mathrm{if}}=1 \text { if } \mathrm{R}_{\mathrm{if}}{ }^{*}>0 \text { and } \mathrm{R}_{\mathrm{if}}=0 \text { if } \mathrm{R}_{\mathrm{if}}{ }^{*} \leq 0
\end{aligned}
$$

Here $\operatorname{Age}_{m}=\left[\left(\operatorname{Age}_{m}-60\right),\left(\text { Age }_{m}-60\right)^{2}, \ldots,\left(\text { Age }_{m}-60\right)^{n}\right]$

$$
\operatorname{Age}_{\mathrm{f}}=\left[\left(\mathrm{Age}_{\mathrm{f}}-60\right),\left(\mathrm{Age}_{\mathrm{f}}-60\right)^{2}, \ldots,\left(\mathrm{Age}_{\mathrm{f}}-60\right)^{\mathrm{n}}\right]
$$

The dummies $D_{m}$ and $D_{f}$ for whether the two partners have reached age 60 (here, 720 months of age) are included in the retirement equations but excluded from the hours equations: the probability to retire changes discontinuously when reaching age 60 (and also when the spouse reaches age 60), but given retirement status, hours are assumed to be a continuous function of age (as usual in a regression discontinuity approach). In contrast, the day of the month the survey was carried out $\mathrm{S}$ is expected to affect hours but not retirement.

The vectors $\mathrm{Z}_{\mathrm{m}}$ and $\mathrm{Z}_{\mathrm{f}}$ contain individual covariates (education and nationality dummies), number of children, the local unemployment rate, cohort dummies and year dummies; Age is a polynomial of order $\mathrm{n}$ in age minus 60 (720 months), which is fully interacted in the retirement equations with the dummies for being 60 or older (as customary in RD 
regressions). In our preferred specification, we use quartic polynomials in age of partners $(n=4)$. Increasing further the order of polynomials did not improve the fit. The Greek letters denote vectors of coefficients. The v's are normally distributed errors, independent of S, Z and the ages of both partners.

Because spouses are on average a few years apart we can identify the effect of the retirement of the husband (instrumented with the dummy for the husband being age 60 and above, $D_{m}$ ) on the hours of the wife; and vice-versa the effect of the retirement of the wife (instrumented with a dummy for the wife being age 60 and above, $\mathrm{D}_{\mathrm{f}}$ ) on the hours of the husband.

In the model, we allow for the 1993 policy change by adding full interactions of the P93 terms (equal to one for cohorts born after 1933 and survey years greater than 1993; and to zero otherwise) with the dummies $D_{m}$ and $D_{f}$ and with all the interactions of these dummies with the Age polynomials (all these extra terms are not shown in equations $\mathrm{c}$ and $\mathrm{d}$ above for conciseness, but see Table 7).

The four equations will be estimated jointly with simulated maximum likelihood. The error terms in the four equations are allowed to be correlated with each other.

As a robustness check for our specification, we also estimate similar instrumental variable models ${ }^{7}$ for the hours of each partner separately, as in a conventional fuzzy RD design.

\section{The data}

The data for the analysis are drawn from the French Labour Force Surveys (LFS) 1990-2002. We use this sample cut for a number of reasons. First of all, these yearly surveys are highly comparable over time as they use the same questionnaire, the same data collection method (personal interviews at the respondent's home) and the same sample design approach. The LFS series was broken in 2003 to comply with Eurostat requirements. The recent LFS series (as from 2003) are carried out quarterly and most of them are done by telephone; and the questionnaire and the sample design have changed dramatically relative to the earlier 1990-

\footnotetext{
${ }^{7}$ Instrumenting own and partner's retirement with the dummies $D_{m}$ and $D_{f}$ for whether the two partners have reached age 60 fully interacted with quartic polynomials in age minus 60 (720 months) of the partners; and also interacting all these instruments with the differences-in- differences term, "P93".
} 
2002 surveys. Next to this, another reform of the length of the pension contribution period took place in 2003, exactly at the time of the break in the LFS series.

Therefore, we select a sample of couples from the 1990-2002 yearly LFS as follows:

- Individuals were matched to their partner if any

- Single people were dropped from the sample

- Same sex couples were dropped from the sample

- Multi-couple households where dropped

- Records from the different survey years were pooled together.

This gave a sample of 588654 couples $^{8}$. Next to this, we selected couples for the analysis as follows:

1. -Both partners were aged between 50 (600 months) and 70 (840 months), which gave a sample of 148395 couples.

2. -both were dual-earner or retirees (dropping other inactive partners, i.e. dropping 60127 couples)

3. -Couples were formally married (we dropped 2795 cohabitant couples).

This gave a final sample of 85473 couples. To apply a regression discontinuity approach we use ten years (120 months) bounds on the two sides of the discontinuity, at age 60, which is the legal early retirement age for most workers in France.

We also test for the robustness of the results of estimation of our model to selecting a sample of couples with at least one spouse aged between 50 (600 months) and 70 (840 months), and then applying selection criteria 2 and 3 above, which gave a sample of 129785 couples. And we test for the robustness of the results to selecting narrower bandwidths on the two sides of the age discontinuity.

The LFS collects month and year of birth together with records of the day, month and year of the interview. We assume that age is continuously measured. Retirement status is measured on the interview date. Our measure of hours is usual weekly hours of work.

\footnotetext{
${ }^{8}$ Descriptive statistics for this sample are provided in Table $\mathrm{C}$ of the Appendix to the paper, while Table $\mathrm{A}$ of the Appendix gives descriptive statistics for this sample setting RD bounds of ten years on both sides of the age cut-off and Table B shows sample descriptives for this sample by retirement status on the two sides of the age discontinuity.
} 
Education refers to completed years of education. The reference category includes individuals with elementary education. As mentioned before, individuals with higher levels of education are likely to enter the labour market later and thus to postpone retirement.

The number of children includes children younger than 18 years at the time of the survey. This variable may affect retirement as individuals with younger children are probably less likely to retire since retirement induces a drop in income (pension benefits are smaller than earnings). Besides, the presence of relatively young children may also affect work hours.

The most disaggregated area of residence available in the survey is the department. France is divided into 22 regions that are further subdivided into 95 departments - without considering the overseas territories (French Guyana, Guadeloupe, Martinique, Mayotte, Ile de la Reunion) that were not covered by these surveys. The level of the unemployment rate may affect the individual retirement probability as, for example, employers may encourage older workers to retire at recessionary times. Therefore, we construct a measure of the local unemployment rate, using the level of the departmental unemployment rate in the year before each survey was carried out -which gives 95 department $* 13$ survey values for the local unemployment rate.

We also include year dummies in all the regressions of the model to capture macroeconomic changes like the secular increase in female labour supply. Year and cohort dummies also serve as controls for the differences-in-differences specification.

Finally, the survey provides information on the day of the month the survey was carried out, which we use to identify hours in our model. Firms are likely to receive orders that have to be fulfilled for given dates and usually activity is more intense shortly before the end of the month to meet these demands. Because over 95per cent (and even over 99 percent in some years) of the LFS interviews were carried out in March of each year, we do not use the month of the survey information here.

\section{Descriptive statistics and exploratory analysis}

Descriptive statistics of the main sample for analysis, dual-earners and retirees spouses aged 50 to 70 years, are provided in Table $1 .^{9}$ The wife is on average 2 years younger than the

\footnotetext{
${ }^{9}$ Descriptive statistics for the sample including all inactive partners aged 50 to 70 years are provided in Table A of the Appendix.
} 
husband. About 60 percent of married men and 48 percent of married women in our sample are aged 60 or above. Half of our sample has an elementary school diploma, which is the reference category for the education dummies in the econometric model. About 30 percent of the men and 27 percent of the women have completed middle school; while about 6 percent of the men and 8.5 percent of the women have a high school diploma. The proportion of college graduates is slightly larger for men, (10 percent) than for women (8 percent), knowing that the proportion of college graduates increases over time and faster for women than men, so that in recent years this pattern is reversed. We control for year dummies in all the equations of the model. About 97 percent of the spouses had the French nationality. The average number of children younger than 18 years is 0.30 , knowing that the couples in the sample are aged between 50 and 70 years. The local unemployment rate was very high on average and equal to 9 percent. As mentioned before (see section 3), there is lot of variation in the unemployment rate, which is allowed to vary over the 95 French departments and over the thirteen years covered by the sample. Finally, about 63 percent of men and 50 percent of women had retired from work, while average week hours, for those still working, were 42 for men and 34 for women.

Table 2 provides descriptive statistics of the sample in Table 1, split on the two sides of the age cut-off (of age below and above 720 months) and by retirement status. ${ }^{10}$ As anticipated (see Section 2), college educated spouses are less likely to retire at early retirement age. The number of dependent children also correlates negatively with retiring early.

Non-parametric evidence on the behaviour of the retirement probability on the two sides of the age cut-off point is gathered in Charts 1, which show the results of non-parametric kernel smoothed estimation of the probability of retirement as a function of age polynomials on the two-sides of the age cut-off point (720 months, which is the legal early retirement age for most workers in France). We let the retirement probability vary, respectively, as a function of own age polynomials (left-hand charts) or, alternatively, spouse's age polynomials (righthand charts). We also plot 95 confidence bounds around each curve -given the large sample size these confidence bounds basically coincide with the predicted probability curves. There are large jumps in both spouses' retirement probability when spouses reach age 60 . We also observe small jumps in the husband's retirement probability when the wife reaches age 60; and, vice-versa, in the wife's retirement probability when the husband reaches age 60.

\footnotetext{
${ }^{10}$ Similar descriptive statistics for the sample including all inactive partners aged 50 to 70 years are provided in Table $B$ of the Appendix.
} 
Charts 2 provide similar information for hours. Hours drop dramatically for both spouses at the legal early retirement age cut-off. We also detect a small drop in the hours of the husband when the wife is aged 720 months or more; and, vice-versa, we see a small drop in her hours when he is aged 720 months or more. The 95 confidence bounds are very close to the predicted probabilities curves and never cross, thus suggesting the these cross-effects are statistically significant for both spouses.

Next to this, we present some exploratory analysis of the changes in the retirement probability of spouses following the 1993 policy change, which essentially required younger cohorts born after 1933 to pay longer pension contribution periods, to be able to receive maximum (full) pension benefits upon retirement (see Section 2). The policy change was voted in the summer of 1993 and it came into force in 1994. The LFS surveys 1990-2002 were carried between January and May of each year, and over 95 percent of these yearly interviews were carried out in the month of March -in particular, in 1993, over 99 percent of the respondents were interviewed in March. Therefore, we assume that 1994 and later years are "policy" year, and 1990 to 1993 are "control" years (see Section 2).

Descriptive statistics of the control and treatment group for dual-earner spouses of all ages are shown in Table 3. Because the policy hit younger cohorts, spouses in the treatment group are on average more educated and have more children, than those in the control group. However, one can reasonably assume that in the absence of the 1993 reform, the retirement probabilities of the spouses in the two groups would have evolved in a comparable manner ${ }^{11}$.

Table 4 gives the raw estimates of the retirement effect of the 1993 policy change, respectively, for husbands and wives, in the policy year, 1994; over the first three years of implementation of the policy, 1994-1996; and over all of the policy years included in our sample, 1994-2002. Probit estimates are provided in Table 5, including among the covariates education and nationality dummy, the number of children and the local unemployment rate. According to the raw estimates, the effect of the 1993 policy change on the retirement probability of both spouses was small, negative and decreasing over time. The probit (marginal) estimates indicate an average reduction on the retirement probability of 0.039 for married men and between 0.027 and 0.045 for married women (see Table 5).

\footnotetext{
${ }^{11}$ Other age-targeted policies were addressed to the unemployed that are not included in our sample. Descriptive statistics for the sample of all ages including all inactive partners are provided in Table C. We present raw differences-in-differences estimates of the 1993 policy change for the larger sample, including all inactive couples, in Tables D and $E$ of the Appendix. Also there we find significantly negative raw estimates of the effect of the 1993 reform on average retirement rates of spouses.
} 
In Table 6, we show the raw estimates of the cross retirement effect of the 1993 policy change, i.e. the effect on the retirement probability of the husband if the wife was concerned by the policy change; and vice-versa, the effect on the retirement probability of the wife if the husband was concerned by the policy change. These effects are significantly negative though quite small for married women; while they are not so significant and even positive over the ten years period for married men.

The descriptive evidence gathered confirms earlier findings (see Bozio, 2004) that the 1993 policy change delayed retirement of individuals. Here, we expect that this policy change reduced the chances to retire at the legal early retirement age for the spouses hit by the policy, by making them less likely to have accumulated enough pension contributions to receive maximum pension benefits, if they retired at the legal early retirement age. Therefore, we combine (interact) in our econometric model controls for the discontinuity at the legal early retirement age with controls for the effect of the 1993 policy change (see Section 2).

\section{Estimation Results}

First of all, we provide results of estimation of bivariate probits models of spouses' retirement (equations $\mathrm{c}$ and $\mathrm{d}$ in Section 2). Next, the results of estimation of the four simultaneous equations model of spouses' hours and spouse's retirement (equations a, b, c and $\mathrm{d}$ in Section 2) are presented.

Table 7 presents the results of estimation of 'first stage ${ }^{12}$ bivariate probits models of the retirement probability of the two spouses (equations c and d of Section 2). As anticipated, we find that the retirement probability jumps up significantly at the legal early retirement age for both spouses. The retirement probability of the husband increases when the wife reaches the legal early retirement age. Her retirement probability does not increase when he reaches legal retirement age. We conclude that the 1993 policy change reduces significantly the probability that the husband retires at the legal early retirement age. The coefficient on the interaction between her being affected by the 1993 policy change and her being 720 months old or more in the retirement equation of the husband is also negative but not statistically significant. This term is negative also in her retirement equation but not statistically significant. Although the interaction term for whether the 1993 policy change affected the wife and her being aged 60 does not have a significant effect on the husband's retirement

\footnotetext{
${ }^{12}$ We provide these results of estimation and various robustness checks for completeness.
} 
probability, two of the interaction terms of her age polynomials with the dummy for her age at least 60 and the corresponding interaction terms with her policy 93 dummy are statistically significant in his retirement equation (see column two of Table 7). Only one of the interaction terms of his age polynomials with the dummy for his age at least 60 is statistically significant in her retirement equation. None of the interactions with his 1993 policy dummy are significant in her retirement equation (see column two of Table 7).

These effects are robust to the exclusion of controls for the 1993 reform (columns 4 and 5 of Table 7) and of covariates (columns 6 and 7 of Table 7).

As shown in Table 8 (specification 1), the retirement probability of the husband increases by $0.22(0.30$ minus 0.08$)$ if is he is aged at least 60 years and is also affected by the 1993 policy change; and by 0.30 if he is aged at least 60 years but he is not affected by the 1993 policy change. His retirement probability increases by an extra 0.05 if his wife is also aged 720 months or more. Her retirement probability increases by 0.33 when she reaches 720 months of age (60 years) while it is not significantly affected by the husband reaching early retirement age nor by whether the husband or the wife are affected by the 1993 policy change.

Had we not controlled for the 1993 policy change, we would conclude that his retirement increases, on average, by 0.27 upon reaching age 60 (specification 2 of Table 8). Splitting the sample between the pre-1993-policy years and the post-1993-policy years (remember this policy was implemented in 1994), we find that his retirement probability increases by 0.25 upon reaching age 60 in the post-policy years (specification 4 of Table 8), against 0.319 in the pre-policy years (specification 5 of Table 8).

His retirement probability is not sensitive to her being aged at least 60 in the post-policy years ${ }^{13}$ (specification 5 of Table 8 ), while this effect is significant at the 5 percent level and equal to 0.067 in the pre-policy years. This can be explained by the fact that the effect of her being aged at least 60 on his retirement probability is positive while that of her being affected by the 1993 policy reform is negative. Thus, ignoring the effect of the 1993 policy in the

\footnotetext{
${ }^{13}$ This confirms earlier finding by Stancanelli and Van Soest (2012a and 2012b), who studied the effect of spouses' retirement on home production and leisure, using a small dataset of about 1000 couples for 1998-99, and concluded that spouses' retirement probability is not significantly affected by whether their partner is aged 60 and above. This finding does not affect the validity of the results in Stancanelli and Van Soest (2012a and 2012b) as the authors use the discontinuity at his (her) age 60 in his (her) retirement probability to identify the husband (wife) retirement probability.
} 
post-policy years makes the estimated coefficient on her being aged at least 60 in his retirement equation insignificant, which supports our specification approach.

Further robustness checks for our 'first stage' specification are provided in Table 9, where we test for the sensitivity of the estimation results to dropping covariates from the spouses' bivariate probit model of retirement (specification 2 of Table 9); dropping the 1993 policy interaction terms and also all the covariates (specification 3 of Table 9); restricting the estimation sample to dual-earners spouses aged between 52 and 68 years (specification 4 of Table 9); restricting the estimation sample to dual-earners spouses aged between 54 and 66 years (specification 5 of Table 9); expanding to sample to include dual-earners spouses with at least one spouse aged between 50 and 70 years (specification 6 of Table 9). We conclude that our specification is robust to all these checks. In particular, the estimates of the coefficients of interest are almost identical across our preferred specification (1) and specifications 2, 4, and 6; they are only slightly smaller in size in specifications 3 and 5.

Finally, the results of estimation of the four-equation model of spouses' retirement and hours are given in Table 10. The correlations of the errors of the four equations are reported in Table 11.

We conclude that hours of both spouses fall significantly upon own and partner's retirement. In particular, the cross-effects are statistically significant and negative: his retirement reduces her hours and, vice-versa, her retirement reduces his hours. On average, her hours fall by 2.7 per cent when he retires while his hours fall by 5 per cent when she retires (see Table 12), implying a reduction of one hour per week for married women and two hours for married men, if their spouse retires.

The estimated coefficients on the dummies for the spouses being aged at least 60 years -that identify retirement in the spouses' hours equations in our model (see Section 2) - are remarkably close to the estimates from the first stage equations (Table 7, columns two and three), as reasonable. We also show a selected set of the dummies for the day of the month of the interview, for which the reference category is the first day of the month -and that we use to identify the hours equations in our model. The estimates suggest that hours of both spouses fall in the first days of the month and increase on the last day of the month.

As far as the other covariates go, residents with French nationality retire before those without, possibly because those not holding a French passport are more likely to have worked abroad 
or to have arrived in France later and, thus, they have probably contributed fewer pension contributions into the French pension system, which creates a disincentive for them to retire earlier. The French nationality of the husband does not affect hours of either spouse. On the contrary, we find that French women work longer hours and they also "make" their spouse work longer hours. The higher his education level, the later the husband retires and the lesser hours he works. Women married to someone with high school or college education also work shorter hours and retire later, at least if the husband has college education. When the husband has middle or high education, women retire earlier than when the husband has elementary education but these coefficients are only weakly significant. Women with more education retire earlier than women with primary education (the reference category), possibly because low-educated women have more spells that are not covered by pension contributions (notably more unemployment at the beginning of their work career). Middle and high educated women are also found to work significantly longer hours than their low-educated counterparts (the reference category) while college educated women work shorter hours (like college educated husbands). Men married to a college educated woman also work shorter hours than man married to a low-educated woman but they retire significantly later than men married to a low-educated wife. As we said above, more educated men retire later than men with primary education and women married to someone with college education also retire later than those married to someone with a low-education level. The number of children reduces significantly the probability of retiring for both spouses and it also reduces working hours of women, while it increases the hours of men. The level of the local unemployment rate has a significantly negative effect on the hours of both spouses and a positive effect on the husband's retirement probability, though very small.

We also find significant and positive correlations between the spouses' hours equations. The correlations of the spouses' retirement equations are also positive and significant. This suggests that unobservable variables determining spouses' decisions are positively correlated, like, for example, leisure preferences.

Various robustness checks were performed (see Table 13). We conclude that our estimates of the effects of spouses' retirement on spouses' hours prove robust.

We rerun the model without allowing for the 1993 policy change (specification 2 of Table 13), to find that our estimates of the effect of spouses' retirement on spouses' hours were remarkably unaffected. This indicated that the discontinuity in age at the legal early 
retirement age is enough to identify retirement in our model and one does not need to control also for the 1993 policy change, at least if the aim of the study is to gather an estimate of the effect of retirement on hours.

Next to this, we expanded the sample to include dual-earner couples with at least one spouse aged 50 to 70 years (specification 3 of Table 13). This serves as a test for the robustness of the estimates to imposing the regressions discontinuity bounds to at least one of the two spouses, rather than to both. The sample size is 129785 couples (see also Section 3). Using this broader regression discontinuity design did not affect the significance or the direction of the effects of spouses' retirement on spouses' hours, although the estimated effect of his retirement on his hours became slightly smaller (the estimated coefficient is -14.19 , against 16.02 in our preferred specification) and the cross-effect of his retirement on her hours slightly larger (the estimated coefficient is -2.030 , against -1.437 in our preferred specification).

Restricting the sample to dual-earner couples with age bounds 52 to 68 years (specification 4 of Table 13), to test for the robustness of the estimates to narrowing the width of the regressions discontinuity sample bounds, did not affect substantially the estimates of spouses' retirement on spouses' hours. The estimated coefficient of his retirement in his hours equation became slightly smaller in absolute value (equal to -13.84 now).

To provide more insights on our identification approach, we also re-estimated the model assuming that spouses' retirement decisions were exogenous to spouses' hours decisions (specification 5 of Table 13), i.e. dropping the retirement equations from the model and thus, only estimating the two simultaneous equations for hours, including dummies for own and spouses' retirement among the regressors (equations $\mathrm{a}$ and $\mathrm{b}$ in Section 2). Under this specification, the estimated effect of own retirement on hours becomes larger for the husband and smaller for the wife, relative to our preferred model (specification 1). The estimated cross effect of the husband's retirement on the wife's hours is twice as large. The effect of wife's retirement on husband's hours appears quite robust, suggesting that husbands may take their retirement decision first, possibly because they are usually older and thus approach (early) retirement age first.

Finally, we estimated two-stages least squares regressions of the hours of the husband and the wife separately (specification 6 of Table 13), instrumenting spouses' retirement with the dummies for each spouse being at least 60 years old interacted with quartic polynomials of 
spouse's age from the left and the right of age 60 (as in our 4 simultaneous equations model). Under this framework, which is the standard approach in the literature for the "fuzzy" RD design (at least when it applies to individuals considered in isolation one from the other), the sign and the significance of the effects of spouses' retirement on spouses' hours are not affected, though the estimated coefficients are much smaller for the husband's hours IV equation and slightly larger for the wife's hours IV equation, relative to our specification (specification 1 in Table 13 and Table 10). To sum up, the own and cross-effects of spouses' retirement on spouses' hours stay negative and strongly significant when estimating two stages least squares hours equations separately for husband and wife, however their size is much smaller, in absolute values, for the husband and slightly larger, in absolute values, for the wife. Re-estimating the IV model entering only the husband's regressors in the husband's IV model (specification not listed in the table), we still get an estimate of - 6 for the effect of his retirement on his hours (as specification 6 of Table 13), while in our model this estimate is equal to -16 .

\section{Conclusions}

The objective of this study is to estimate the causal effect of spouses' retirement on spouses' hours. To this end, we exploit legal early retirement age in France and a retirement policy change.

We specify four simultaneous equations of retirement and hours of spouses. We use a regression discontinuity approach combined with differences-in-differences to identify spouses' retirement in our model. The day of the survey is used to identify hours -firms receive orders that typically have to be satisfied by a certain day of the month.

The model is estimated with data on over 85000 dual-earner couples with spouses aged 50 to 70. Exploratory graphical analysis indicates very large jumps in the own retirement probability at the legal early retirement age for both spouses. The retirement probability also jumps up when the partner reaches age 60 (cross-effects), though the cross-effects are much smaller than the own effects. Own hours are found to fall dramatically with own retirement and to decrease further with spouse's retirement -suggesting negative cross-effects of partner's retirement on own hours on the basis of non-parametric graphical analysis.

Parametric estimation confirms these findings. The own retirement probability increases significantly at the legal retirement age for both men and women in a couple: the increase in 
the retirement probability is equal to 0.30 for married men and 0.33 for married women. We conclude that the 1993 reform that required younger cohorts born after 1933 to pay longer pension contribution periods, reduced the probability to retire at the early retirement age for married men (by 0.08) while the effect was not significant for married women. Married men are also more likely to retire (by 0.05) if their wife reaches early retirement age while the opposite is not true for married women. We conclude that hours of both spouses fall significantly upon own and partner's retirement. On average, her hours fall by 2.7 per cent when he retires while his hours fall by 5 per cent when she retires, implying an average reduction of one hour per week for married women and two hours for married men, if their spouse retires.

These findings are robust to selecting couples with at least one spouse aged 50 to 70 , or narrowing the bounds for the regression discontinuity design, and various other robustness checks.

\section{References}

Baker, M. (2002). The Retirement Behavior of Married Couples: Evidence from the Spouse's Allowance, Journal of Human Resources, 37(1), 1-34.

Battistin, Erich, Agar Brugiavini, Enrico Rettore and Guglielmo Weber (2009), The Retirement Consumption Puzzle: Evidence from a Regression Discontinuity Approach American Economic Review, 99(5), 2209-2226.

Blanchet, Didier and Louis-Paul Pele (1997), Social Security and Retirement in France, NBER Working Paper No. 6214.

Blau D.M. (1998), Labor Force Dynamics of Older Married Couples, Journal of Labor Economics, 16(3), 595-629.

Bommier , Antoine, Thierry Magnac and Muriel Roger, (2003). "Le marché du travail à l'approche de la retraite : évolutions en France entre 1982 et 1999," Revue Française d'Economie, 18 (1), pp. 27-82.

Bourguignon, François and Thierry Magnac, (1990), "Labor Supply and Taxation in France," Journal of Human Resources, University of Wisconsin Press, vol. 25(3), pp. 358-389

Bozio, Antoine (2004), "Does Increasing Contribution Length Lead to Higher Retirement Age? Evidence from the 1993 French Pension Reform", mimeo.

Gustman, Alan and Thomas Steinmeier (2009), Integrating Retirement Models, NBER Working Paper 15607. 
Gustman, Alan and Thomas Steinmeier (2000), Retirement in Dual-Career Families: A Structural Model, Journal of Labor Economics, 18, 503-545.

Jean-Olivier Hairault, Francois Langot and Thepthida Sopraseuth (2010), "Distance to Retirement and Older Workers' Employment: The Case for Delaying the Retirement Age", Journal of the European Economic Association, MIT Press, vol. 8(5), pages 1034-1076, 09.

Imbens, Guido and Thomas Lemieux (2007), Regression Discontinuity Design: a Guide to Practice, Journal of Econometrics, 142, 615-635.

Kapur, Kanika and Jeannette Rogowski (2007), 'The role of health insurance in joint retirement among married couples', Industrial and Labor Relations Review, 60 (3), pp. 397407.

Van der Klaauw, Wilbert (2008), Regression-Discontinuity Analysis: A Survey of Recent Developments in Economics, Labour, 22(2), 219-245.

Van der Klaauw, Wilbert (2002), Estimating the Effect of Financial Aid Offers on College Enrollment: A Regression-Discontinuity Approach, International Economic Review, 43(4), 1249-1287.

Lee, David S. and Thomas Lemieux (2010), Regression Discontinuity Designs in Economics, Journal of Economic Literature, 48(2), 281-355.

Roodman, David (2009), Estimating Fully Observed Recursive Mixed-Process Models with CMP. Working Papers 168, Center for Global Development.

Roodman, David (2007), CMP: Stata Module to Implement Conditional (Recursive) Mixed Process Estimator. Statistical Software Components S456882, Boston College Department of Economics, revised 22 May 2009.

Stancanelli, Elena, "Evaluating the impact of the French Tax Credit on the employment rate of women", Journal of Public Economics, October 2008, Vol. 92, No. 10-11, pp. 2036-47.

Stancanelli, Elena and Arthur Van Soest (2012a), Retirement and Home Production: A Regression Discontinuity approach, American Economic Review, Papers and Proceedings, 102(3), 600-605.

Stancanelli, Elena and Arthur Van Soest (2012b), Joint Leisure Before and After Retirement: a double Regression Discontinuity approach, IZA DP 6698.

Van Soest, Arthur and Elena Stancanelli (2010), “Does Income Taxation Affects Partners' Household Chores, IZA DP 5038. 


\begin{tabular}{|c|c|c|c|c|}
\hline \multirow[t]{2}{*}{ Table 1.} & \multicolumn{4}{|c|}{ Sample descriptives } \\
\hline & \multicolumn{2}{|r|}{ Husband } & \multicolumn{2}{|r|}{ Wife } \\
\hline Age & $\begin{array}{c}\text { Mean } \\
61.233\end{array}$ & $\begin{array}{c}\text { Standard dev. } \\
5.467\end{array}$ & $\begin{array}{c}\text { Mean } \\
59.279\end{array}$ & $\begin{array}{c}\text { Standard dev. } \\
5.526\end{array}$ \\
\hline Age 60 and above & 0.597 & 0.490 & 0.476 & 0.499 \\
\hline Elementary School & 0.523 & 0.499 & 0.564 & 0.495 \\
\hline Middle School & 0.298 & 0.457 & 0.266 & 0.442 \\
\hline High School & 0.066 & 0.249 & 0.085 & 0.279 \\
\hline College & 0.109 & 0.312 & 0.081 & 0.274 \\
\hline French & 0.971 & 0.166 & 0.978 & 0.146 \\
\hline Retired & 0.635 & 0.481 & 0.508 & 0.499 \\
\hline \multirow[t]{2}{*}{ Usual Hours } & 42.18 & 12.861 & 33.898 & 13.720 \\
\hline & \multicolumn{3}{|c|}{ Couple's characteristics } & \\
\hline Children number & & $\begin{array}{l}\text { Mean } \\
0.325\end{array}$ & $\begin{array}{c}\text { Standard dev. } \\
0.652\end{array}$ & \\
\hline Local U rate & & 9.222 & 2.36 & \\
\hline Observations no. & \multicolumn{4}{|l|}{85473} \\
\hline \multicolumn{5}{|c|}{$\begin{array}{l}\text { Note: The sample includes dual-earners and retired spouses aged } 50 \text { to } 70 \text {. } \\
\text { Hours are averaged over positive values of hours. The local U rate is the year } \\
\text { (t-1) unemployment rate at the department level (there are } 95 \text { departments). U } \\
\text { rate varies across departments and over the } 13 \text { LFS years. }\end{array}$} \\
\hline
\end{tabular}




\begin{tabular}{|c|c|c|c|c|}
\hline \multirow{2}{*}{ 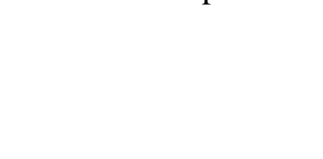 } & \multirow{2}{*}{$\begin{array}{l}\text { Not Retired } \\
\text { Age 50-59 }\end{array}$} & \multicolumn{3}{|c|}{ Men in a Couple } \\
\hline & & $\begin{array}{l}\text { Retired } \\
\text { Age 50-59 }\end{array}$ & $\begin{array}{l}\text { Not Retired } \\
\text { Age } 60-70\end{array}$ & $\begin{array}{l}\text { Retired } \\
\text { Age } 60-70\end{array}$ \\
\hline Elementary School & $\begin{array}{l}0.366 \\
(0.481)\end{array}$ & $\begin{array}{l}0.463 \\
(0.498)\end{array}$ & $\begin{array}{l}0.445 \\
(0.497)\end{array}$ & $\begin{array}{l}0.628 \\
(0.483)\end{array}$ \\
\hline Middle School & $\begin{array}{l}0.382 \\
(0.485)\end{array}$ & $\begin{array}{l}.0376 \\
(0.484)\end{array}$ & $\begin{array}{l}0.193 \\
(0.395)\end{array}$ & $\begin{array}{l}0.245 \\
(0.430)\end{array}$ \\
\hline High School & $\begin{array}{l}0.083 \\
(0.277)\end{array}$ & $\begin{array}{l}0.077 \\
(0.267)\end{array}$ & $\begin{array}{l}0.082 \\
(0.275)\end{array}$ & $\begin{array}{l}0.054 \\
(0.226)\end{array}$ \\
\hline College & $\begin{array}{l}0165 \\
(0.371)\end{array}$ & $\begin{array}{l}0.082 \\
(0.274)\end{array}$ & $\begin{array}{l}0.276 \\
(0.276)\end{array}$ & $\begin{array}{l}0.070 \\
(0.255)\end{array}$ \\
\hline French & $\begin{array}{l}0.963 \\
(0.187)\end{array}$ & $\begin{array}{l}0.979 \\
(0.143)\end{array}$ & $\begin{array}{l}0.947 \\
(0.222)\end{array}$ & $\begin{array}{l}0.976 \\
(0.151)\end{array}$ \\
\hline Children number & $\begin{array}{l}0.588 \\
(0.813)\end{array}$ & $\begin{array}{l}0.323 \\
(0.624)\end{array}$ & $\begin{array}{l}0.353 \\
(0.669)\end{array}$ & $\begin{array}{l}0.170 \\
(0.474)\end{array}$ \\
\hline Local U rate & $\begin{array}{l}9.107 \\
(2.350)\end{array}$ & $\begin{array}{l}9.263 \\
(2.367)\end{array}$ & $\begin{array}{l}9.128 \\
(2.336)\end{array}$ & $\begin{array}{l}9.290 \\
(2.365)\end{array}$ \\
\hline \multirow[t]{3}{*}{ Observations no. } & 28334 & 6053 & 2829 & 48257 \\
\hline & \multicolumn{4}{|c|}{ Women in a Couple } \\
\hline & $\begin{array}{l}\text { Not Retired } \\
\text { Age } 50-59\end{array}$ & $\begin{array}{l}\text { Retired } \\
\text { Age 50-59 }\end{array}$ & $\begin{array}{l}\text { Not Retired } \\
\text { Age } 60-70\end{array}$ & $\begin{array}{l}\text { Retired } \\
\text { Age } 60-70\end{array}$ \\
\hline Elementary School & $\begin{array}{l}0.479 \\
(0.499)\end{array}$ & $\begin{array}{l}0.421 \\
(0.493)\end{array}$ & $\begin{array}{l}0.654 \\
(0.475)\end{array}$ & $\begin{array}{l}0.667 \\
(0.470)\end{array}$ \\
\hline Middle School & $\begin{array}{l}0.309 \\
(0.462)\end{array}$ & $\begin{array}{l}0.302 \\
(0.459)\end{array}$ & $\begin{array}{l}0.188 \\
(0.391)\end{array}$ & $\begin{array}{l}0.224 \\
(0.417)\end{array}$ \\
\hline High School & $\begin{array}{l}0.101 \\
(0.301)\end{array}$ & $\begin{array}{l}0.135 \\
(0.342)\end{array}$ & $\begin{array}{l}0.072 \\
(0.259)\end{array}$ & $\begin{array}{l}0.062 \\
(0.241)\end{array}$ \\
\hline College & $\begin{array}{l}0.108 \\
(0.311)\end{array}$ & $\begin{array}{l}0.140 \\
(.347)\end{array}$ & $\begin{array}{l}0.081 \\
(0.273)\end{array}$ & $\begin{array}{l}0.044 \\
(0.205)\end{array}$ \\
\hline French & $\begin{array}{l}0.969 \\
(0.171)\end{array}$ & $\begin{array}{l}0.983 \\
(0.127)\end{array}$ & $\begin{array}{l}0.961 \\
(0.193)\end{array}$ & $\begin{array}{l}0.987 \\
0.111)\end{array}$ \\
\hline Children number & $\begin{array}{l}0.537 \\
(0.788)\end{array}$ & $\begin{array}{l}0.272 \\
(0.601)\end{array}$ & $\begin{array}{l}0.238 \\
(0.548)\end{array}$ & $\begin{array}{l}0.124 \\
(0.397)\end{array}$ \\
\hline Local U rate & $\begin{array}{l}9.114 \\
(2.338)\end{array}$ & $\begin{array}{l}9.223 \\
(2.391)\end{array}$ & $\begin{array}{l}9.296 \\
(2.359)\end{array}$ & $\begin{array}{l}9.326 \\
(2.373)\end{array}$ \\
\hline Observations no. & 38319 & 6392 & 3653 & 37109 \\
\hline
\end{tabular}


Chart 1. Own and partner's retirement probability at the legal early retirement age cut-off Kernel smoothed polynomials from the left and the right of the age cutoff ( 720 months)
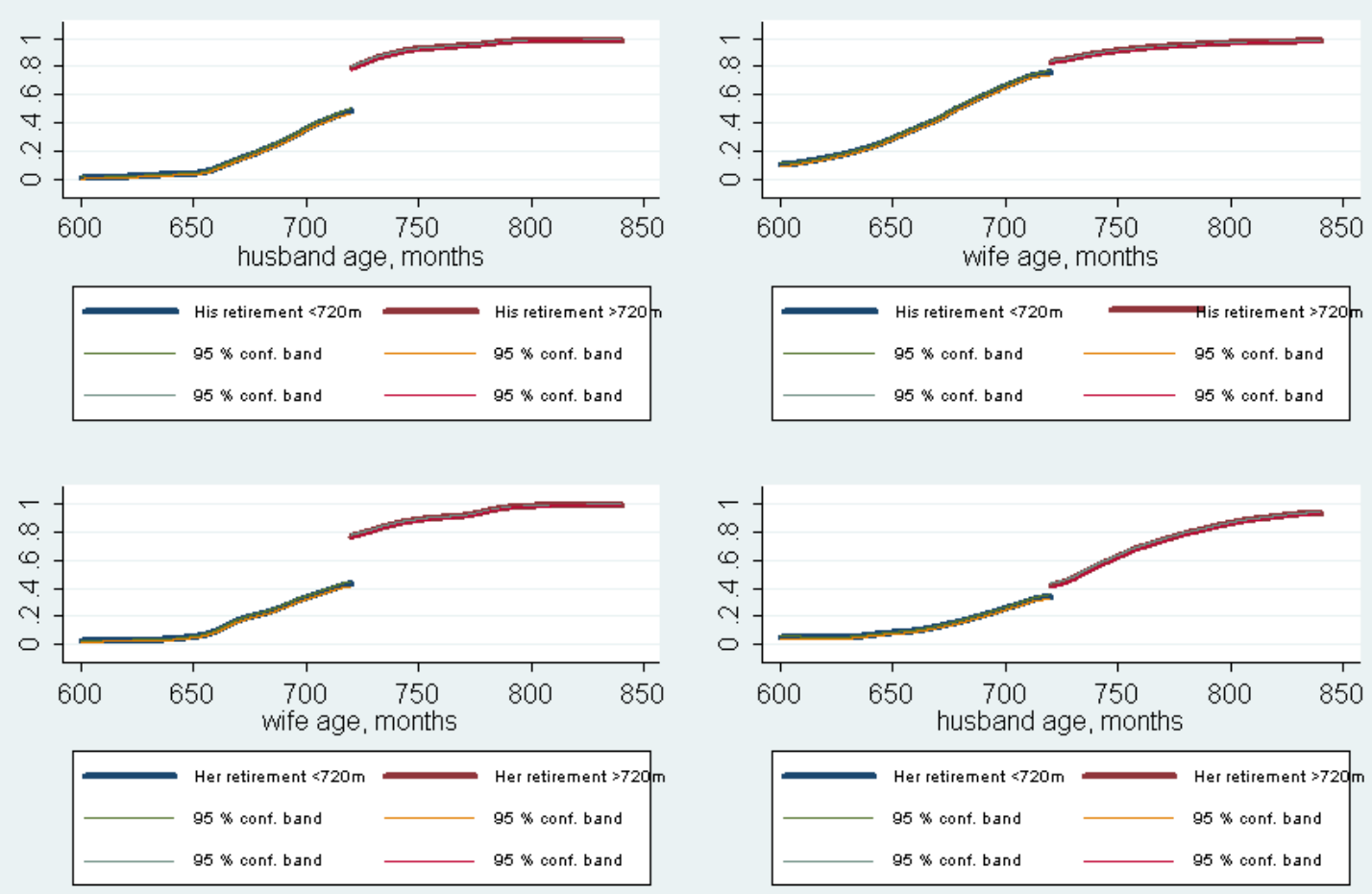
Chart 2. Own and partner's hours at the legal early retirement age cut-off Kernel smoothed polynomials from the left and right of the age cut-off (720 months)
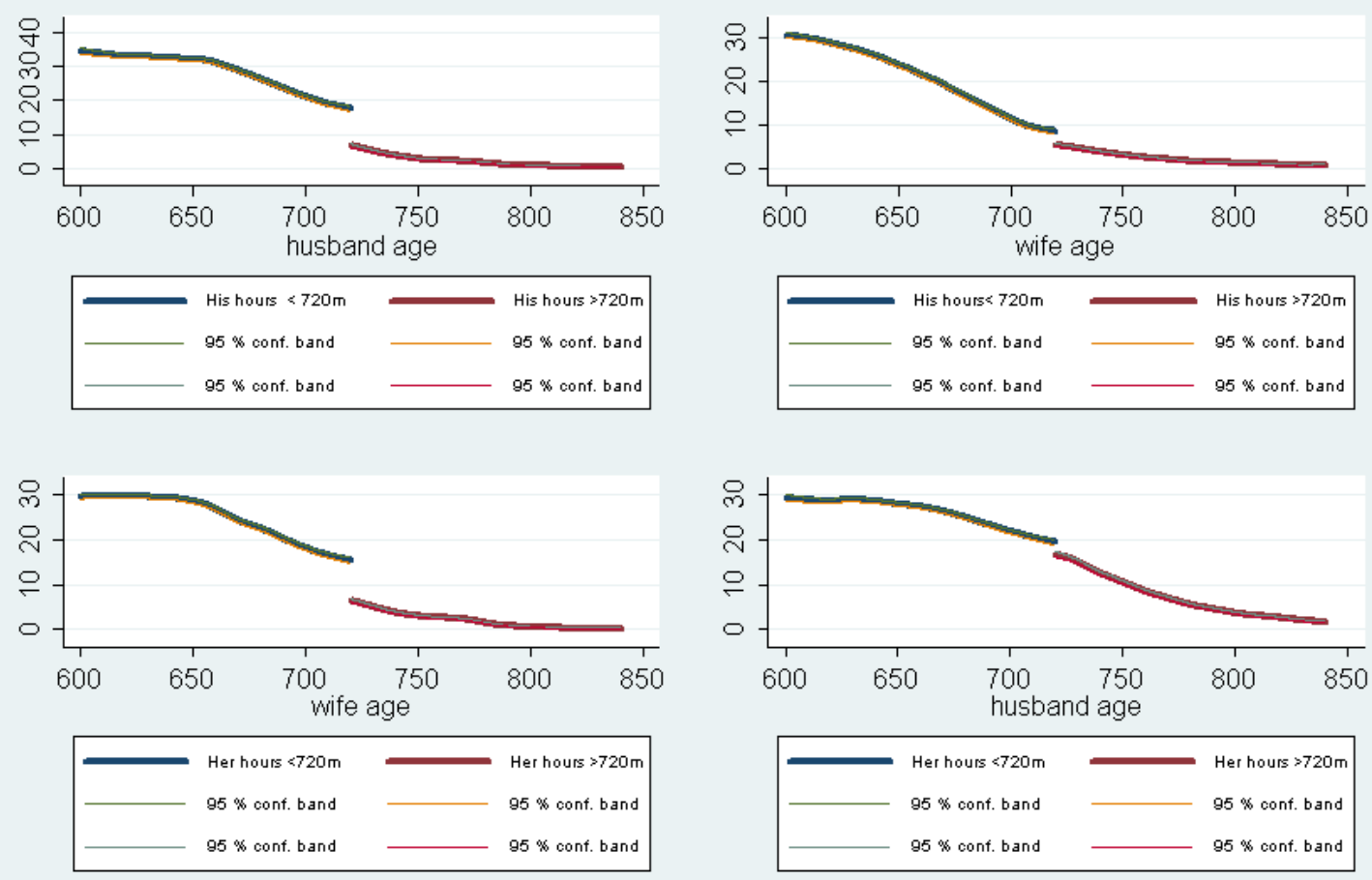


\begin{tabular}{|c|c|c|c|c|}
\hline & \multicolumn{2}{|c|}{ Husband control group } & \multicolumn{2}{|c|}{ Husband treatment group } \\
\hline & Mean & St. Deviation & Mean & St. Deviation \\
\hline Elementary School & 0.543 & 0.498 & 0.266 & 0.442 \\
\hline Middle School & 0.274 & 0.446 & 0.438 & 0.496 \\
\hline High School & 0.075 & 0.264 & 0.109 & 0.311 \\
\hline College & 0.103 & 0.304 & 0.185 & 0.388 \\
\hline French & 0.969 & 0.171 & 0.956 & 0.202 \\
\hline Children number & 0.646 & 0.96 & 1.291 & 1.065 \\
\hline Local U rate & 8.851 & 2.284 & 9.554 & 2.409 \\
\hline \multirow[t]{3}{*}{ Observations number } & 157970 & & 164244 & \\
\hline & \multicolumn{2}{|c|}{ Wife control group } & \multicolumn{2}{|c|}{ Wife treatment group } \\
\hline & Mean & St. Deviation & Mean & St. Deviation \\
\hline Elementary School & 0.557 & 0.496 & 0.298 & 0.457 \\
\hline Middle School & 0.255 & 0.436 & 0.357 & 0.479 \\
\hline High School & 0.102 & 0.303 & 0.175 & 0.38 \\
\hline College & 0.081 & 0.273 & 0.168 & 0.374 \\
\hline French & 0.977 & 0.149 & 0.964 & 0.184 \\
\hline Children number & 0.67 & 0.971 & 1.235 & 1.072 \\
\hline Local U rate & 8.802 & 2.27 & 9.558 & 2.407 \\
\hline Observations number & 148583 & & 173631 & \\
\hline
\end{tabular}




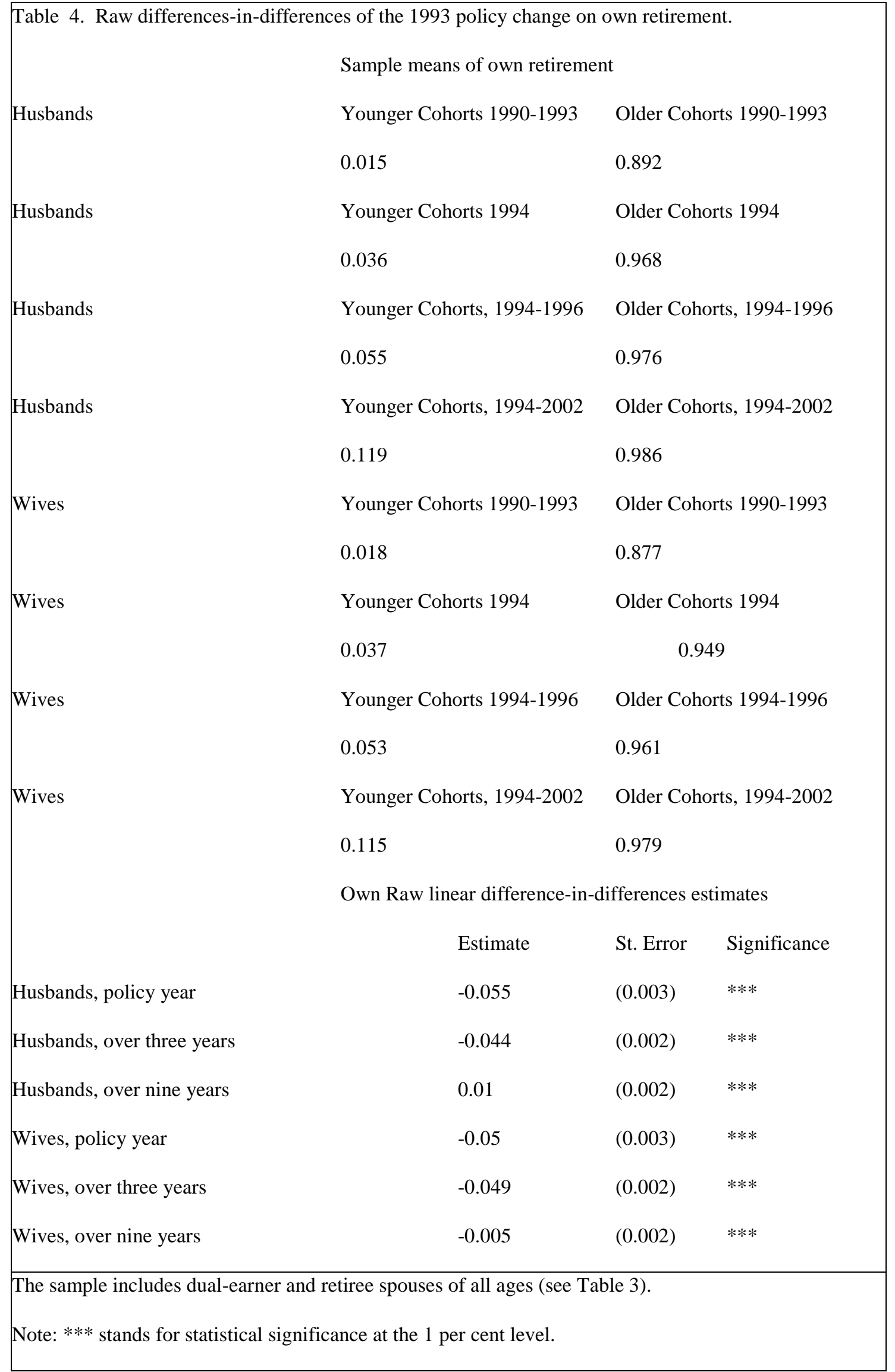




\begin{tabular}{|c|c|c|c|}
\hline \multicolumn{4}{|c|}{ Marginal Effects of the 1993 Policy Change on the Own Retirement Probability } \\
\hline & Estimate & St. Error & Significance \\
\hline Husbands, policy year & -0.039 & $(0.007)$ & $* * *$ \\
\hline Husbands, over three years & -0.038 & $(0.006)$ & $* * *$ \\
\hline Husbands, over nine years & -0.039 & $(0.007)$ & $* * *$ \\
\hline Wives, policy year & -0.027 & $(0.006)$ & $* * *$ \\
\hline Wives, over three years & -0.028 & $(0.005)$ & $* * *$ \\
\hline Wives, over nine years & -0.045 & $(0.006)$ & $* * *$ \\
\hline \multicolumn{4}{|c|}{$\begin{array}{l}\text { The probits of retirement include -in addition to birth cohort and year dummies- controls for } \\
\text { education dummies, nationality, local unemployment rate and number of children younger } \\
\text { than } 18 \text {. }\end{array}$} \\
\hline \multicolumn{4}{|c|}{ The sample includes dual-earner and retiree spouses of all ages. } \\
\hline Note: $* * *$ stands for statisti & gnificance & t level. & \\
\hline
\end{tabular}


Table 6. Cross raw differences-in-differences of the effect of the 1993 reform on retirement

Sample Means of Own Retirement when the Spouse is affected by the policy

Wife Y. Cohorts 1990-1993 Wife O. Cohorts 1990-1993

Husbands R. 0.054

0.917

Wife Y. Cohorts 1994

Wife O. Cohorts 1994 0.090

$$
0.960
$$

Wife Y. Cohorts, 1994-1996

Wife O. Cohorts, 1994-1996

Husbands R

$$
0.106
$$

0.970

Wife Y. Cohorts, 1994-2002

Husbands R

$$
0.167
$$

Wife O. Cohorts, 1994-2002

0.982

Wives R

Husband Y. Cohorts 19901993

0.017

Husband O. Cohorts 1990-1993

0.778

Wives R.

Husband Y. Cohorts 1994 0.031

Husband O. Cohorts 1994

0.854

Wives R

Husband Y. Cohorts 19941996

0.04

Husband O. Cohorts 1994-1996

0.877

Wives R.

Husband Y. Cohorts, 1994-2002 0.088

Husband O. Cohorts, 1994-2002

0.921

Cross raw linear difference-in-differences

Husbands, policy year

Husbands, over three years

Husbands, over nine years

Wives, policy year

Wives, over three years

Wives, over nine years

The sample includes dual-earner and retiree spouses of all ages.

Note: $* * *$ stands for statistical significance at the 1 per cent level.

Y. Young and O. Old.

We measure here the raw effects on the husband' s (wife' s) retirement probability of the fact that their partner is concerned by the 1993 policy change. These are indirect (cross) effects of the policies on spouses' retirement.

\section{Estimate}

$-0.007$

$-0.0010$

0.048

$-0.06$

(0.003)

(0.002) $\quad * * *$

\section{Error}

$$
-0.076
$$

$0.001) \quad * * *$




\begin{tabular}{|c|c|c|c|c|c|c|}
\hline \multirow{4}{*}{ He Age $60 \&$ above= Dm } & \multicolumn{2}{|c|}{ With Covariates \& 93 Policy } & \multicolumn{2}{|c|}{ Covariates, without 93 Policy } & \multicolumn{2}{|c|}{ No Covariates or 93 Policy } \\
\hline & He Retir. & She Retir. & He Retir. & She Retir. & He Retir. & She Retir. \\
\hline & $0.904 * * *$ & 0.0314 & $0.798 * * *$ & 0.0252 & $0.765 * * *$ & 0.0228 \\
\hline & $(0.0509)$ & $(0.0532)$ & $(0.0342)$ & $(0.0361)$ & $(0.0336)$ & $(0.0359)$ \\
\hline \multirow[t]{2}{*}{ She Age $60 \&$ above=Df } & $0.167 * * *$ & $0.862 * * *$ & $0.114 * * *$ & $0.864 * * *$ & $0.133 * * *$ & $0.853 * * *$ \\
\hline & $(0.0587)$ & $(0.0488)$ & $(0.0411)$ & $(0.0326)$ & $(0.0402)$ & $(0.0324)$ \\
\hline \multirow[t]{2}{*}{ P93* He Age $60 \&$ above } & $-0.234 * * *$ & -0.00272 & & & & \\
\hline & $(0.0651)$ & $(0.0660)$ & & & & \\
\hline \multirow[t]{2}{*}{ P93* She Age $60 \&$ above } & -0.104 & -0.0993 & & & & \\
\hline & $(0.0762)$ & $(0.0619)$ & & & & \\
\hline \multirow[t]{2}{*}{ Dm $(\text { Agem- } 60)^{2}$} & $0.147 * * *$ & $0.0493 * * *$ & $0.200 * * *$ & $0.0442 * * *$ & $0.202 * * *$ & $0.0416^{* * *}$ \\
\hline & $(0.0211)$ & $(0.0181)$ & $(0.0155)$ & $(0.0131)$ & $(0.0151)$ & $(0.0130)$ \\
\hline \multirow[t]{2}{*}{ Dm $\left(\right.$ Agem-60) ${ }^{3}$} & -0.000170 & -0.00109 & $-0.00184 * *$ & -0.000901 & $-0.00200 * * *$ & $-0.000964 *$ \\
\hline & $(0.000920)$ & $(0.000702)$ & $(0.000761)$ & $(0.000568)$ & $(0.000739)$ & $(0.000566)$ \\
\hline \multirow[t]{2}{*}{$\operatorname{Dm}\left(\right.$ Agem-60) ${ }^{4}$} & $-2.42 \mathrm{e}-05$ & $8.14 \mathrm{e}-05$ & 0.000106 & $6.42 \mathrm{e}-05$ & $0.000122 *$ & $7.14 \mathrm{e}-05$ \\
\hline & $(8.05 \mathrm{e}-05)$ & $(5.95 \mathrm{e}-05)$ & $(6.88 \mathrm{e}-05)$ & $(4.97 \mathrm{e}-05)$ & $(6.67 \mathrm{e}-05)$ & $(4.95 \mathrm{e}-05)$ \\
\hline \multirow{2}{*}{$(1-\mathrm{Dm})\left(\right.$ Agem-60) ${ }^{2}$} & $0.171^{* * *}$ & 0.0306 & $0.215^{* * *}$ & 0.0152 & $0.221 * * *$ & 0.00933 \\
\hline & $(0.0220)$ & $(0.0231)$ & $(0.0144)$ & $(0.0161)$ & $(0.0142)$ & $(0.0160)$ \\
\hline \multirow[t]{2}{*}{$(1-\mathrm{Dm})\left(\right.$ Agem-60) ${ }^{3}$} & $0.00349^{* *}$ & 0.000565 & $0.00366^{* * * *}$ & 0.000567 & $0.00337 * * *$ & 0.000701 \\
\hline & $(0.00137)$ & $(0.00134)$ & $(0.000765)$ & $(0.000786)$ & $(0.000758)$ & $(0.000781)$ \\
\hline \multirow[t]{2}{*}{$(1-\mathrm{Dm})\left(\right.$ Agem-60) ${ }^{4}$} & $0.000351^{* * * *}$ & $5.73 \mathrm{e}-05$ & $0.000392^{* * * *}$ & $4.27 \mathrm{e}-05$ & $0.000362^{* * *}$ & $5.27 \mathrm{e}-05$ \\
\hline & $(0.000134)$ & $(0.000125)$ & $(7.16 \mathrm{e}-05)$ & $(7.14 \mathrm{e}-05)$ & $(7.10 \mathrm{e}-05)$ & $(7.09 \mathrm{e}-05)$ \\
\hline \multirow{2}{*}{ Df $(\text { Agef-60) })^{2}$} & 0.0221 & $0.139 * * *$ & 0.0232 & $0.146^{* * *}$ & $0.0377 * *$ & $0.146^{* * *}$ \\
\hline & $(0.0252)$ & (0.0209) & $(0.0188)$ & $(0.0151)$ & $(0.0183)$ & $(0.0150)$ \\
\hline \multirow[t]{2}{*}{ Df $(\text { Agef-60) })^{3}$} & -0.000452 & $0.00263^{* * *}$ & -0.000657 & $0.00202 * *$ & -0.000934 & $0.00213^{* * *}$ \\
\hline & $(0.00115)$ & $(0.00101)$ & $(0.000957)$ & $(0.000827)$ & $(0.000931)$ & $(0.000824)$ \\
\hline \multirow[t]{2}{*}{ Df(Agef-60) $)^{4}$} & $6.26 \mathrm{e}-05$ & $-0.000256^{* * *}$ & $8.16 \mathrm{e}-05$ & $-0.000191 * *$ & $9.75 \mathrm{e}-05$ & $-0.000202^{* * *}$ \\
\hline & $(0.000103)$ & $(9.22 \mathrm{e}-05)$ & $(8.83 \mathrm{e}-05)$ & $(7.85 \mathrm{e}-05)$ & $(8.59 \mathrm{e}-05)$ & $(7.82 \mathrm{e}-05)$ \\
\hline \multirow[t]{2}{*}{$(1-D f)(\text { Agef-60) })^{2}$} & 0.0110 & $0.139 * * *$ & $0.0244 *$ & $0.147 * * *$ & 0.0168 & $0.145^{* * *}$ \\
\hline & $(0.0205)$ & $(0.0193)$ & $(0.0143)$ & $(0.0131)$ & $(0.0140)$ & $(0.0130)$ \\
\hline \multirow[t]{2}{*}{$(1-D f)\left(\right.$ Agef-60) ${ }^{3}$} & $0.00213^{* *}$ & $0.00312 * * *$ & 0.000150 & $0.00459 * * *$ & 0.000321 & $0.00471 * * *$ \\
\hline & $(0.000971)$ & $(0.00104)$ & $(0.000589)$ & $(0.000609)$ & $(0.000580)$ & $(0.000605)$ \\
\hline \multirow[t]{2}{*}{$(1-D f)\left(\right.$ Agef-60) ${ }^{4}$} & $0.000213 * *$ & $0.000329^{* * *}$ & $2.20 \mathrm{e}-05$ & $0.000465^{* * *}$ & $2.96 \mathrm{e}-05$ & $0.000472 * * *$ \\
\hline & $(8.68 \mathrm{e}-05)$ & $(9.50 \mathrm{e}-05)$ & $(5.07 \mathrm{e}-05)$ & $(5.41 \mathrm{e}-05)$ & $(5.01 \mathrm{e}-05)$ & $(5.36 \mathrm{e}-05)$ \\
\hline P93m Dm (Agem-60) ${ }^{2}$ & $0.169^{* * *}$ & -0.01000 & & & & \\
\hline & $(0.0398)$ & $(0.0325)$ & & & & \\
\hline P93m Dm (Agem-60) ${ }^{3}$ & $-0.0123^{* * *}$ & 0.000429 & & & & \\
\hline & $(0.00344)$ & $(0.00223)$ & & & & \\
\hline P93m Dm(Agem-60) ${ }^{4}$ & $0.00148^{* * *}$ & $6.54 \mathrm{e}-06$ & & & & \\
\hline & $(0.000427)$ & $(0.000251)$ & & & & \\
\hline P93m (1-Dm ) (Agem-60) ${ }^{2}$ & $0.0606^{* * *}$ & -0.0145 & & & & \\
\hline & $(0.0233)$ & $(0.0240)$ & & & & \\
\hline P93m (1-Dm) (Agem-60) & $9.90 \mathrm{e}-05$ & -0.000209 & & & & \\
\hline & $(0.00155)$ & $(0.00152)$ & & & & \\
\hline P93m (1-Dm) (Agem-60) & $4.57 \mathrm{e}-05$ & $-3.58 \mathrm{e}-05$ & & & & \\
\hline & $(0.000152)$ & $(0.000144)$ & & & & \\
\hline P93f Df (Agef-60) $)^{2}$ & 0.0371 & $0.162 * * *$ & & & & \\
\hline & $(0.0464)$ & $(0.0391)$ & & & & \\
\hline P93f Df (Agef-60) ${ }^{3}$ & -0.00345 & $-0.0229 * * *$ & & & & \\
\hline & $(0.00371)$ & $(0.00392)$ & & & & \\
\hline P93f Df(Agef-60) ${ }^{4}$ & 0.000401 & $0.00313^{* * *}$ & & & & \\
\hline & $(0.000440)$ & $(0.000534)$ & & & & \\
\hline P93f (1-Df ) (Agef-60) ${ }^{2}$ & 0.0318 & 0.00916 & & & & \\
\hline & $(0.0208)$ & $(0.0202)$ & & & & \\
\hline
\end{tabular}


Table 9. Bivariate probit models of Joint Retirement. Robustness checks

Marginal estimates of the effect of reaching age 60 and above

\begin{tabular}{|c|c|c|c|c|c|}
\hline He Retires & & & She Retires & & \\
\hline Coefficient & St. Error & Significance & Coefficient & St. Error & \\
\hline
\end{tabular}

(1) Preferred specification, with 93 Policy interactions and covariates (see Table 6 )

He is 60 \& above

$0.306 \quad 0.0172 \quad * * *$

0.012

0.021

She is $60 \&$ above

$0.0548 \quad 0.019 \quad * *$

0.332

$0.017 * * *$

P93* He Age 60 \& above

$-0.0805 \quad 0.023 \quad * * *$

$-0.001$

0.026

P93* She Age $60 \&$ above

$-0.0349$

0.026

$-0.039$

0.024

(2) With 93 Policy interactions, without covariates

He is $60 \&$ above

$\begin{array}{rrr}0.301 & 0.017 & * * * \\ 0.064 & 0.019 & * * * \\ -0.085 & 0.023 & * * * \\ -0.04 & 0.026 & \end{array}$

0.007

0.333

0.021

She is $60 \&$ above

$-0.04 \quad 0.026$

0.004

$0.017 * * *$

P93* He Age $60 \&$ above

P93* She Age $60 \&$ above

ut covariates

He is $60 \&$ above

$0.262 \quad 0.011 * * *$

0.262

$0.013 * * *$

$-0.044$

0.026

$0.024 *$

She is $60 \&$ above

(4) Preferred specification, with 93 Policy interactions and covariates, Age Bounds 52-68

0.009

0.014

$\mathrm{He}$ is 60 \& above

$\begin{array}{rrl}0.306 & 0.019 & * * * \\ 0.053 & 0.02 & * * \\ -0.076 & 0.024 & * * \\ -0.028 & 0.026 & \end{array}$

0.006

0.329

0.011

0.011

$0.011 * * *$

She is $60 \&$ above

$-0.028$

0.026

$-0.009$

$0.023 * * *$

0.02

0.028

P93* She Age 60 \& above

$\begin{array}{ccl}0.253 & 0.023 & * * * \\ 0.051 & 0.023 & * * \\ -0.061 & 0.026 & * * \\ -0.022 & 0.029 & \end{array}$

$-0.002$

0.027

(5) Preferred specification, with 93 Policy interactions and covariates, Age Bounds 54-64

He is $60 \&$ above

She is $60 \&$ above

0.029

0.269

0.028

$0.024 * * *$

P93* He Age 60 \& above

$\begin{array}{lll}0.306 & 0.012\end{array}$

0.013

0.033

P93* She Age 60 \& above

$\begin{array}{rrl}0.306 & 0.012 & * * * \\ 0.039 & 0.015 & * * \\ -0.095 & 0.020 & * * * \\ -0.011 & 0.023 & \end{array}$

0.022

0.031

(6) Preferred specification, with 93 Policy interactions and covariates, sample includes at least one spouse aged 50 to 70 $\mathrm{He}$ is $60 \&$ above

She is $60 \&$ above

P93* He Age $60 \&$ above

$-0.011$

0.023

0.022

$0.015 * * *$

0.271

$0.014 * * *$

P93* She Age $60 \&$ above

*** stands for statistical significance at the 1 per cent level; ** at the 5 per cent and $*$ at the 10 per cent 


\begin{tabular}{|c|c|c|c|c|}
\hline & His Hours & Her Hours & His Retirement & Her Retirement \\
\hline His Retirement & $\begin{array}{c}-16.02 * * * \\
(0.875)\end{array}$ & $\begin{array}{c}-1.437 * * \\
(0.660)\end{array}$ & & \\
\hline Her Retirement & $\begin{array}{c}-4.267 * * * \\
(0.829)\end{array}$ & $\begin{array}{c}-15.29 * * * \\
(1.124)\end{array}$ & & \\
\hline He French & $\begin{array}{l}0.0623 \\
(0.732)\end{array}$ & $\begin{array}{c}0.857 \\
(0.645)\end{array}$ & $\begin{array}{c}0.325 * * * \\
(0.0662)\end{array}$ & $\begin{array}{c}0.121 * \\
(0.0628)\end{array}$ \\
\hline He Middle School & $\begin{array}{c}-0.547 * * * \\
(0.189)\end{array}$ & $\begin{array}{l}-0.0251 \\
(0.173)\end{array}$ & $\begin{array}{c}-0.0466 * * * \\
(0.0162)\end{array}$ & $\begin{array}{l}0.0260 * \\
(0.0153)\end{array}$ \\
\hline He High School & $\begin{array}{c}-1.185 * * * \\
(0.315)\end{array}$ & $\begin{array}{c}-0.645 * * \\
(0.303)\end{array}$ & $\begin{array}{c}-0.192 * * * \\
(0.0281)\end{array}$ & $\begin{array}{l}0.0525 * \\
(0.0268)\end{array}$ \\
\hline He College & $\begin{array}{c}-1.775^{* * *} \\
(0.300)\end{array}$ & $\begin{array}{c}-1.488 * * * \\
(0.291)\end{array}$ & $\begin{array}{c}-0.609 * * * \\
(0.0267)\end{array}$ & $\begin{array}{c}-0.133 * * * \\
(0.0255)\end{array}$ \\
\hline She French & $\begin{array}{c}4.373 * * * \\
(0.803)\end{array}$ & $\begin{array}{c}3.657 * * * \\
(0.715)\end{array}$ & $\begin{array}{c}0.0659 \\
(0.0746)\end{array}$ & $\begin{array}{l}0.249 * * * \\
(0.0725)\end{array}$ \\
\hline She Middle School & $\begin{array}{l}-0.280 \\
(0.192)\end{array}$ & $\begin{array}{c}1.428 * * * \\
(0.175)\end{array}$ & $\begin{array}{l}-0.00155 \\
(0.0164)\end{array}$ & $\begin{array}{c}0.152 * * * \\
(0.0156)\end{array}$ \\
\hline She High School & $\begin{array}{c}-0.663 * * \\
(0.286)\end{array}$ & $\begin{array}{c}1.659 * * * \\
(0.273)\end{array}$ & $\begin{array}{l}-0.0102 \\
(0.0256)\end{array}$ & $\begin{array}{c}0.295 * * * \\
(0.0246)\end{array}$ \\
\hline She College & $\begin{array}{c}-1.468 * * * \\
(0.311)\end{array}$ & $\begin{array}{c}-1.044 * * * \\
(0.302)\end{array}$ & $\begin{array}{c}-0.181 * * * \\
(0.0291)\end{array}$ & $\begin{array}{c}0.297 * * * \\
(0.0277)\end{array}$ \\
\hline Children number & $\begin{array}{c}0.646 * * * \\
(0.101)\end{array}$ & $\begin{array}{c}-0.563 * * * \\
(0.0965)\end{array}$ & $\begin{array}{c}-0.133 * * * \\
(0.0105)\end{array}$ & $\begin{array}{c}-0.113 * * * \\
(0.0106)\end{array}$ \\
\hline Local U rate & $\begin{array}{c}-0.193 * * * \\
(0.0366)\end{array}$ & $\begin{array}{c}-0.143 * * * \\
(0.0333)\end{array}$ & $\begin{array}{c}0.00652 * * \\
(0.00311)\end{array}$ & $\begin{array}{c}0.00166 \\
(0.00286)\end{array}$ \\
\hline He Age 60 and above & & & $\begin{array}{c}0.911 * * * \\
(0.0510)\end{array}$ & $\begin{array}{c}0.0303 \\
(0.0532)\end{array}$ \\
\hline She Age 60 and above & & & $\begin{array}{c}0.172 * * * \\
(0.0588)\end{array}$ & $\begin{array}{c}0.860 * * * \\
(0.0488)\end{array}$ \\
\hline P93* He Age 60 and above & & & $\begin{array}{c}-0.238 * * * \\
(0.0651)\end{array}$ & $\begin{array}{c}-0.00156 \\
(0.0660)\end{array}$ \\
\hline P93* She Age 60 and above & & & $\begin{array}{c}-0.108 \\
(0.0762)\end{array}$ & $\begin{array}{l}-0.0975 \\
(0.0618)\end{array}$ \\
\hline Interview 4th Day Month & $\begin{array}{c}-1.547 * * \\
(0.651)\end{array}$ & $\begin{array}{c}-1.494 * * \\
(0.596)\end{array}$ & & \\
\hline Interview 5th Day Month & $\begin{array}{c}-1.299 * * \\
(0.644)\end{array}$ & $\begin{array}{c}-1.290 * * \\
(0.590)\end{array}$ & & \\
\hline Interview 6th Day Month & $\begin{array}{c}-1.311 * * \\
(0.637)\end{array}$ & $\begin{array}{l}-0.975^{*} \\
(0.583)\end{array}$ & & \\
\hline Interview 7th Day Month & $\begin{array}{l}-1.218 * \\
(0.636)\end{array}$ & $\begin{array}{c}-1.597 * * * \\
(0.580)\end{array}$ & & \\
\hline Interview 31st Day Month & $\begin{array}{l}2.049 * * \\
(1.011)\end{array}$ & $\begin{array}{c}2.062 * * \\
(0.973)\end{array}$ & & \\
\hline \multicolumn{5}{|c|}{$\begin{array}{l}\text { The estimation sample includes dual-earner and retiree spouses aged } 50 \text { to } 70 \text { years, } 85473 \text { couples. } \\
\text { The four equations are estimated simultaneously by simulated maximum likelihood with } 100 \text { draws. } \\
\text { For conciseness, we only show a subset of the covariates included in the regressions. In particular, we do } \\
\text { not show all estimated coefficients on the quartic polynomials in age and their interactions with the age } \\
\text { cutoff and with the differences-in-differences term (see Table } 7 \text { ). Many interview day dummies are not } \\
\text { shown either (the reference category is the first day of the month) nor the year and cohorts dummies. } \\
* * * \text { stands for statistical significance at the } 1 \text { per cent level; } * * \text { at the } 5 \text { per cent and } * \text { at the } 10 \text { per cent. }\end{array}$} \\
\hline
\end{tabular}




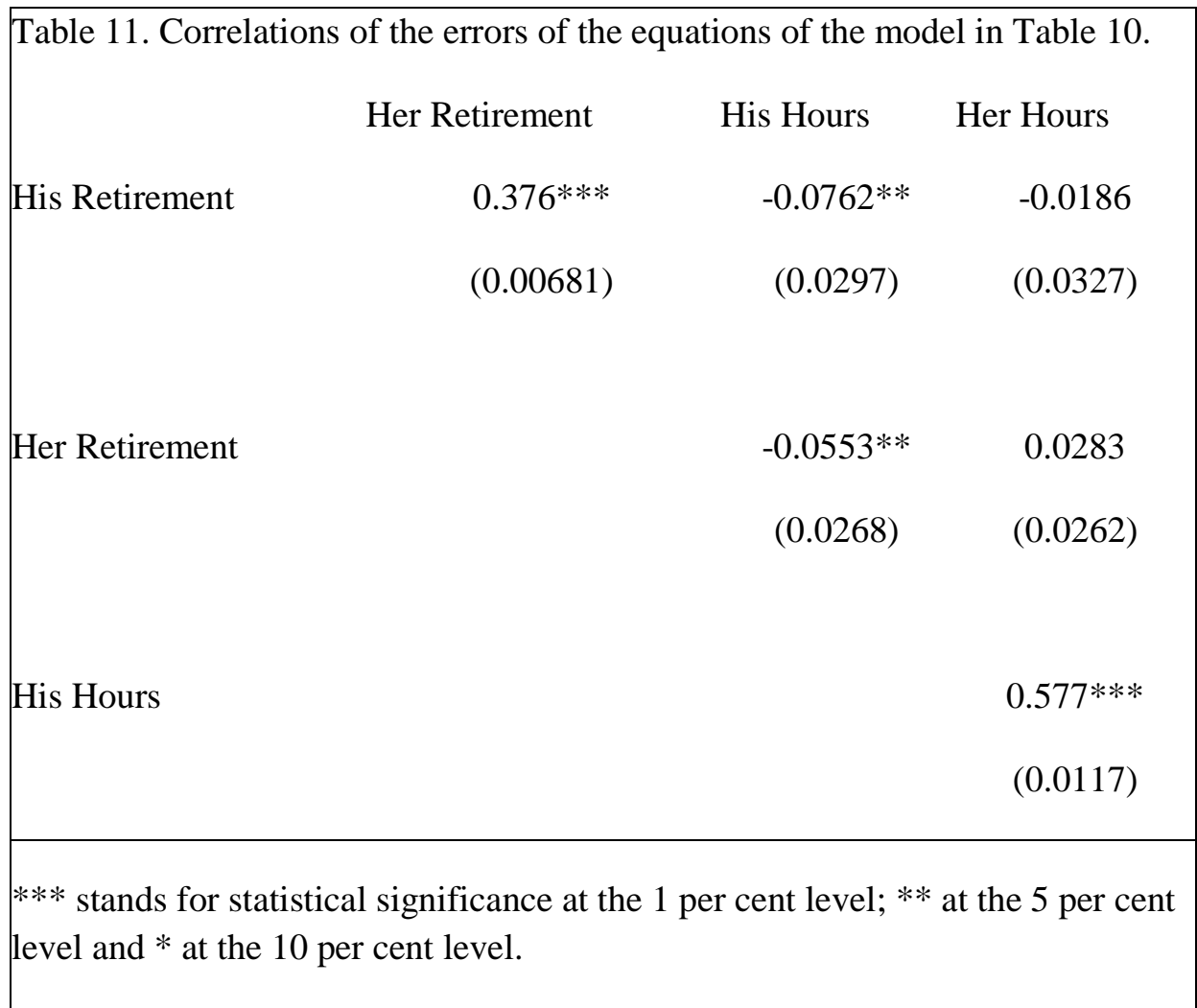

\begin{tabular}{l} 
Table 12. Hours Elasticities to changes in Retirement Status \\
$\qquad \begin{array}{l}\text { His Hours } \\
\text { His Retirement Her Hours }\end{array}$ \\
Her Retirement \\
$\qquad-0.239 * * *$ \\
\hline $\begin{array}{l}\text { These elasticities are calculated at sample means of hours and } \\
\text { retirement, on the basis of the results of estimation of our } \\
\text { preferred model specification (see Table 10). Given the large } \\
\text { sample size and the strong significance of the estimated } \\
\text { coefficients, they are strongly statistically significant. } \\
* * * \text { stands for statistical significance at the } 1 \text { per cent level; } \\
* * \text { at the } 5 \text { per cent level and * at the } 10 \text { per cent level. }\end{array}$ \\
\hline
\end{tabular}


Table 13. Sensitivity checks of the effects of Spouses'Retirement on Hours

His Hours

Her Hours

(1) Preferred model, see Table 10 for full results

His Retirement

$-16.02 * * * \quad-1.437 * *$

(0.875)

(0.660)

Her Retirement

$$
-4.267 * * *
$$

$(0.829)$

(2) Without 1993 policy RD interactions terms

$\begin{array}{lcc} & -16.06 * * * & -1.455^{* * *} \\ \text { His Retirement } & (0.879) & (0.668) \\ & -4.293 * * * & -15.25 * * * \\ \text { Her Retirement } & (0.833) & (1.130)\end{array}$

Her Retirement

(0.833)

(1.130)

(3) Selecting a larger sample with at least one spouse aged 50 to 70
His Retirement
$-14.19 * * *$
$-2.030 * * *$
(0.670)
(0.402)
Her Retiremen
$-4.385 * * *$
$-15.00 * * *$
(0.570)
(0.927)

(4) Setting age bounds for the spouses 52 to 68
His Retirement
$-13.84 * * *$
$-1.383 * * *$
(0.753)
(0.478)
Her Retirement
$-4.357 * * *$
$-15.25 * * *$
(0.655)
(1.010)

(5) Assuming exogenous retirement (dropping the retirement equations)
His Retirement
$-17.79 * * *$
$-2.932 * * *$
$(0.522)$
$(0.214)$
Her Retirement
$-4.270 * * *$
$-14.26 * * *$
(0.294)
$(0.907)$

(6) Using separate $2 S L S I V$ regressions for his hours \& her hours
His Retirement
$-6.146 * * *$
$-1.747 * * *$
(0.968)
$(0.230)$
Her Retirement
$-1.928 * * *$
$-18.24 * * *$
(0.432)
(4.366)

Note: These models include the same covariates as in our preferred specification (see Table 10) unless otherwise specified. Only the effects of retirement on hours are shown here for conciseness. The estimation sample is the same as in Table 10 unless otherwise specified. The same applies for the model specification.

*** stands for statistical significance at the 1 per cent level; ** at the 5 per cent and $*$ at the

10 per cent level. 
Appendix.

Table A. Descriptives, sample including other inactive partners

\begin{tabular}{|c|c|c|c|c|}
\hline Age & $\begin{array}{l}\text { Mean } \\
60.776\end{array}$ & $\begin{array}{c}\text { Standard dev. } \\
5.293\end{array}$ & $\begin{array}{c}\text { Mean } \\
58.617\end{array}$ & $\begin{array}{l}\text { Wife } \\
\text { Standard } \\
\text { dev. } \\
\quad 5.239\end{array}$ \\
\hline Age 60 and above & .553 & .497 & .403 & .490 \\
\hline Elementary School & 0.531 & 0.499 & 0.605 & 0.488 \\
\hline Middle School & 0.292 & 0.454 & 0.252 & 0.434 \\
\hline High School & 0.065 & 0.247 & 0.075 & 0.264 \\
\hline College & 0.109 & 0.312 & 0.063 & 0.244 \\
\hline French & 0.949 & 0.217 & 0.957 & 0.201 \\
\hline Retired & .598 & .490 & .308 & .461 \\
\hline Employed & 0.337 & 0.472 & 0.317 & 0.465 \\
\hline Other Inactive & 0.063 & 0.244 & 0.373 & 0.483 \\
\hline Usual Hours & 41.707 & 11.950 & 33.837 & 13.692 \\
\hline
\end{tabular}

\begin{tabular}{|c|c|c|}
\hline \multirow[b]{2}{*}{ Married } & \multicolumn{2}{|c|}{ Couple's characteristics } \\
\hline & $\begin{array}{l}\text { Mean } \\
0.970\end{array}$ & $\begin{array}{c}\text { Standard dev. } \\
0.169\end{array}$ \\
\hline Children number & 0.393 & 0.773 \\
\hline Local U rate & 9.368 & 2.429 \\
\hline Observations no. & 148395 & \\
\hline
\end{tabular}




\begin{tabular}{|c|c|c|c|c|}
\hline \multicolumn{5}{|c|}{$\begin{array}{l}\text { Table B. Sample descriptives by retirement status on the two sides of the } \\
\text { Men in a Couple }\end{array}$} \\
\hline & Not Retired & Retired & Not Retired & Retired \\
\hline & Age $50-59$ & Age 50-59 & Age $60-70$ & Age $60-70$ \\
\hline \multirow{2}{*}{ Elementary School } & 0.415 & 0.494 & 0.454 & 0.623 \\
\hline & $(0.492)$ & $(0.499)$ & $(0.497)$ & $(0.484)$ \\
\hline \multirow[t]{2}{*}{ Middle School } & 0.353 & 0.364 & 0.180 & 0.245 \\
\hline & $(0.478)$ & $(0.481)$ & $(0.384)$ & $(0.430)$ \\
\hline \multirow[t]{2}{*}{ High School } & 0.077 & 0.068 & 0.080 & 0.055 \\
\hline & $(0.267)$ & $(0.251)$ & $(0.271)$ & $(0.228)$ \\
\hline \multirow[t]{2}{*}{ College } & 0.150 & 0.071 & 0.280 & 0.074 \\
\hline & $(0.357)$ & $(0.257)$ & $(0.449)$ & $(0.262)$ \\
\hline \multirow[t]{2}{*}{ French } & 0.944 & 0.970 & 0.877 & 0.962 \\
\hline & $(0.228)$ & $(0.170)$ & $(0.327)$ & $(0.192)$ \\
\hline \multirow[t]{2}{*}{ Children number } & 0.636 & 0.396 & 0.456 & 0.217 \\
\hline & $(0.922)$ & $(0.768)$ & $(0.868)$ & $(0.579)$ \\
\hline \multirow[t]{2}{*}{ Local U rate } & 9.274 & 9.494 & 9.301 & 9.419 \\
\hline & $(2.44)$ & $(2.429)$ & $(2.409)$ & $(2.419)$ \\
\hline \multirow[t]{4}{*}{ Observations no. } & 53943 & 12271 & 5607 & 76574 \\
\hline & \multicolumn{4}{|c|}{ Women in a Couple } \\
\hline & Not Retired & Retired & Not Retired & Retired \\
\hline & Age 50-59 & Age $50-59$ & Age $60-70$ & Age $60-70$ \\
\hline \multirow[t]{2}{*}{ Elementary School } & 0.560 & 0.424 & 0.723 & 0.668 \\
\hline & $(0.496)$ & $(0.494)$ & $(0.447)$ & $(0.470)$ \\
\hline \multirow[t]{2}{*}{ Middle School } & 0.280 & 0.303 & 0.183 & 0.223 \\
\hline & $(0.449)$ & $(0.459)$ & $(.0387)$ & -0.416 \\
\hline \multirow[t]{2}{*}{ High School } & 0.083 & 0.133 & 0.053 & 0.061 \\
\hline & $(0.276)$ & $(0.340)$ & $(0.224)$ & $(0.240)$ \\
\hline \multirow[t]{2}{*}{ College } & 0.074 & 0.137 & 0.036 & 0.044 \\
\hline & $(0.261)$ & $(0.344)$ & $(0.188)$ & $(0.205)$ \\
\hline \multirow[t]{2}{*}{ French } & 0.944 & 0.983 & 0.944 & 0.986 \\
\hline & -0.228 & $(0.126)$ & $(0.228)$ & (0.114) \\
\hline \multirow[t]{2}{*}{ Children number } & 0.573 & 0.271 & 0.229 & 0.126 \\
\hline & $(0.903)$ & $(0.598)$ & $(0.583)$ & $(0.402)$ \\
\hline \multirow[t]{2}{*}{ Local U rate } & 9.324 & 9.236 & 9.639 & 9.338 \\
\hline & $(2.4349)$ & $(2.402)$ & $(2.492)$ & $(2.379)$ \\
\hline Observations no. & 81619 & 6934 & 20972 & 38870 \\
\hline
\end{tabular}




\begin{tabular}{|c|c|c|c|c|}
\hline \multicolumn{5}{|c|}{ Table C. Sample descriptive, larger sample of all ages } \\
\hline & Mean & $\begin{array}{l}\text { Husband } \\
\text { Standard dev. }\end{array}$ & Mean & $\begin{array}{l}\text { Wife } \\
\text { Standard } \\
\text { dev. }\end{array}$ \\
\hline Age & 49.476 & 15.666 & 46.900 & 15.369 \\
\hline Age 60 and above & 0.273 & 0.445 & 0.228 & 0.419 \\
\hline Elementary School & 0.398 & 0.489 & 0.437 & 0.496 \\
\hline Middle School & 0.355 & 0.478 & 0.303 & 0.459 \\
\hline High School & 0.093 & 0.291 & 0.136 & 0.342 \\
\hline College & 0.149 & 0.356 & .0120 & 0.326 \\
\hline French & 0.937 & 0.242 & 0.945 & 0.227 \\
\hline Retired & 0.286 & 0.452 & 0.176 & 0.381 \\
\hline Employed & 0.643 & 0.478 & 0.492 & 0.499 \\
\hline Other Inactive & 0.069 & 0.254 & 0.331 & 0.470 \\
\hline \multirow[t]{3}{*}{ Usual Hours } & 41.431 & 9.697 & 34.221 & 11.178 \\
\hline & \multicolumn{4}{|c|}{ Couple's characteristics } \\
\hline & & $\begin{array}{l}\text { Mean } \\
0.858\end{array}$ & \multicolumn{2}{|l|}{$\begin{array}{c}\text { Standard dev. } \\
0.348\end{array}$} \\
\hline Children number & & 1.075 & \multicolumn{2}{|l|}{1.20} \\
\hline Local U rate & & 9.384 & \multicolumn{2}{|l|}{2.452} \\
\hline Observations no. & \multicolumn{4}{|l|}{588654} \\
\hline \multicolumn{5}{|c|}{$\begin{array}{l}\text { Note: The sample includes all active and inactive partners, married and } \\
\text { unmarried, and of all ages. } \\
\text { Hours are averaged over positive values of hours. }\end{array}$} \\
\hline
\end{tabular}




\begin{tabular}{|c|c|c|}
\hline & $\begin{array}{l}\text { Own Raw Retirement Pr } \\
\text { Younger Cohorts 1990- }\end{array}$ & lity \\
\hline \multirow[t]{2}{*}{ Husbands } & 1993 & Older Cohorts 1990-1993 \\
\hline & 0.0198 & 0.859 \\
\hline \multirow[t]{2}{*}{ Husbands } & Younger Cohorts 1994 & Older Cohorts 1994 \\
\hline & $\begin{array}{l}0.0389 \\
\text { Younger Cohorts 1994- }\end{array}$ & 0.958 \\
\hline \multirow[t]{2}{*}{ Husbands } & 1995 & Older Cohorts 1994-1995 \\
\hline & $\begin{array}{l}0.0469 \\
\text { Younger Cohorts, 1994- }\end{array}$ & 0.963 \\
\hline \multirow[t]{2}{*}{ Husbands } & 1996 & Older Cohorts, 1994-1996 \\
\hline & $\begin{array}{l}0.054 \\
\text { Younger Cohorts, 1994- }\end{array}$ & 0.966 \\
\hline \multirow[t]{2}{*}{ Husbands } & 2002 & Older Cohorts, 1994-2002 \\
\hline & 0.102 & 0.979 \\
\hline \multirow[t]{2}{*}{ Wives } & $\begin{array}{l}\text { Younger Cohorts 1990- } \\
1993\end{array}$ & Older Cohorts 1990-1993 \\
\hline & 0.01 & 0.583 \\
\hline \multirow[t]{2}{*}{ Wives } & Younger Cohorts 1994 & Older Cohorts 1994 \\
\hline & $\begin{array}{l}0.0203 \\
\text { Younger Cohorts 1994- }\end{array}$ & 0.697 \\
\hline \multirow[t]{2}{*}{ Wives } & 1995 & Older Cohorts 1994-1995 \\
\hline & $\begin{array}{l}0.024 \\
\text { Younger Cohorts 1994- }\end{array}$ & 0.709 \\
\hline \multirow[t]{2}{*}{ Wives } & 1996 & Older Cohorts 1994-1996 \\
\hline & $\begin{array}{l}0.028 \\
\text { Younger Cohorts, 1994- }\end{array}$ & 0.719 \\
\hline \multirow[t]{2}{*}{ Wives } & 2002 & Older Cohorts, 1994-2002 \\
\hline & 0.0626 & 0.762 \\
\hline
\end{tabular}

Own Raw linear difference-in-differences estimates

\begin{tabular}{|c|c|c|c|}
\hline Husbands, policy year & $\begin{array}{l}\text { Estimate } \\
-0.0799\end{array}$ & $\begin{array}{l}\text { St. Error } \\
(0.002)\end{array}$ & $\begin{array}{l}\text { Significance } \\
* * *\end{array}$ \\
\hline Husbands, over two years & -0.0769 & $(0.001)$ & $* * *$ \\
\hline Husbands, over three years & -0.0728 & $(0.001)$ & $* * *$ \\
\hline Husbands, over nine years & -0.0378 & $(0.001)$ & $* * *$ \\
\hline Wives, policy year & -0.10 & $(0.003)$ & $* * *$ \\
\hline Wives, over two years & -0.112 & $(0.002)$ & $* * *$ \\
\hline Wives, over three years & -0.118 & $(0.002)$ & $* * *$ \\
\hline Wives, over nine years & -0.1264 & $(0.002)$ & $* * *$ \\
\hline \multicolumn{4}{|c|}{$\begin{array}{l}\text { The sample includes all active and inactive partners, married and unmarried, of all } \\
\text { ages, ie. the population of couples in the pooled LFS surveys 1990-2002, } 588654 \\
\text { couples. }\end{array}$} \\
\hline
\end{tabular}




\begin{tabular}{|lcc}
\hline Table E. Cross Raw Differences-in-differences estimates & \\
Husbands & Cross Raw Retirement Probability & \\
& Wife Y. Cohorts 1990-1993 & Wife O. Cohorts 1990-1993 \\
Husbands & 0.0644 & 0.8859 \\
& Wife Y. Cohorts 1994 & Wife O. Cohorts 1994 \\
Husbands & 0.0962 & 0.9461 \\
Wife Y. Cohorts 1994-1995 & Wife O. Cohorts 1994-1995 \\
Husbands & 0.103 & 0.9516 \\
Husbands & Wife Y. Cohorts, 1994-1996 & Wife O. Cohorts, 1994-1996 \\
Wives & 0.109 & 0.9559 \\
& Wife Y. Cohorts, 1994-2002 & Wife O. Cohorts, 1994-2002 \\
Wives & 0.1483 & 0.9708 \\
& Husband Y. Cohorts 1990-1993 & Husband O. Cohorts 1990-1993 \\
Wives & 0.011 & 0.49 \\
& Husband Y. Cohorts 1994 & Husband O. Cohorts 1994 \\
Wives & 0.019 & Husband O. Cohorts 1994-1995 \\
Wives & Husband Y. Cohorts 1994-1995 & 0.5846 \\
& Husband Y. Cohorts 1994-1996 & Husband O. Cohorts 1994-1996 \\
& 0.0238 & 0.6107 \\
& 0.0496 & Husband O. Cohorts, 1994-2002
\end{tabular}

Cross Raw linear difference-in-differences estimates

\begin{tabular}{|c|c|c|c|c|}
\hline & Estimate & St. Error & Significance & Sample Size \\
\hline Husbands, policy year & -0.0284 & $(0.003)$ & $* * *$ & 221771 \\
\hline Husbands, over two years & -0.0271 & $(0.002)$ & $* * *$ & 268824 \\
\hline Husbands, over three years & -0.0254 & $(0.002)$ & $* * *$ & 315354 \\
\hline Husbands, over nine years & -0.001 & $(0.002)$ & & 588654 \\
\hline Wives, policy year & -0.09 & $(0.003)$ & $* * *$ & 221771 \\
\hline Wives, over two years & -0.098 & $(0.002)$ & $* * *$ & 268824 \\
\hline Wives, over three years & -0.1079 & $(0.002)$ & $* * *$ & 315354 \\
\hline Wives, over nine years & -0.1469 & $(0.002)$ & $* * *$ & 588654 \\
\hline $\begin{array}{l}\text { The sample includes al } \\
\text { population of couples }\end{array}$ & $\begin{array}{l}\text { active par } \\
\text { FS survey }\end{array}$ & $\begin{array}{l}\text { garried and } \\
-2002 \text {. }\end{array}$ & arried, of & ges, ie. the \\
\hline
\end{tabular}

